\title{
Waterbird Egg Mercury Concentrations in Response to Wetland Restoration in South San Francisco Bay, California
}

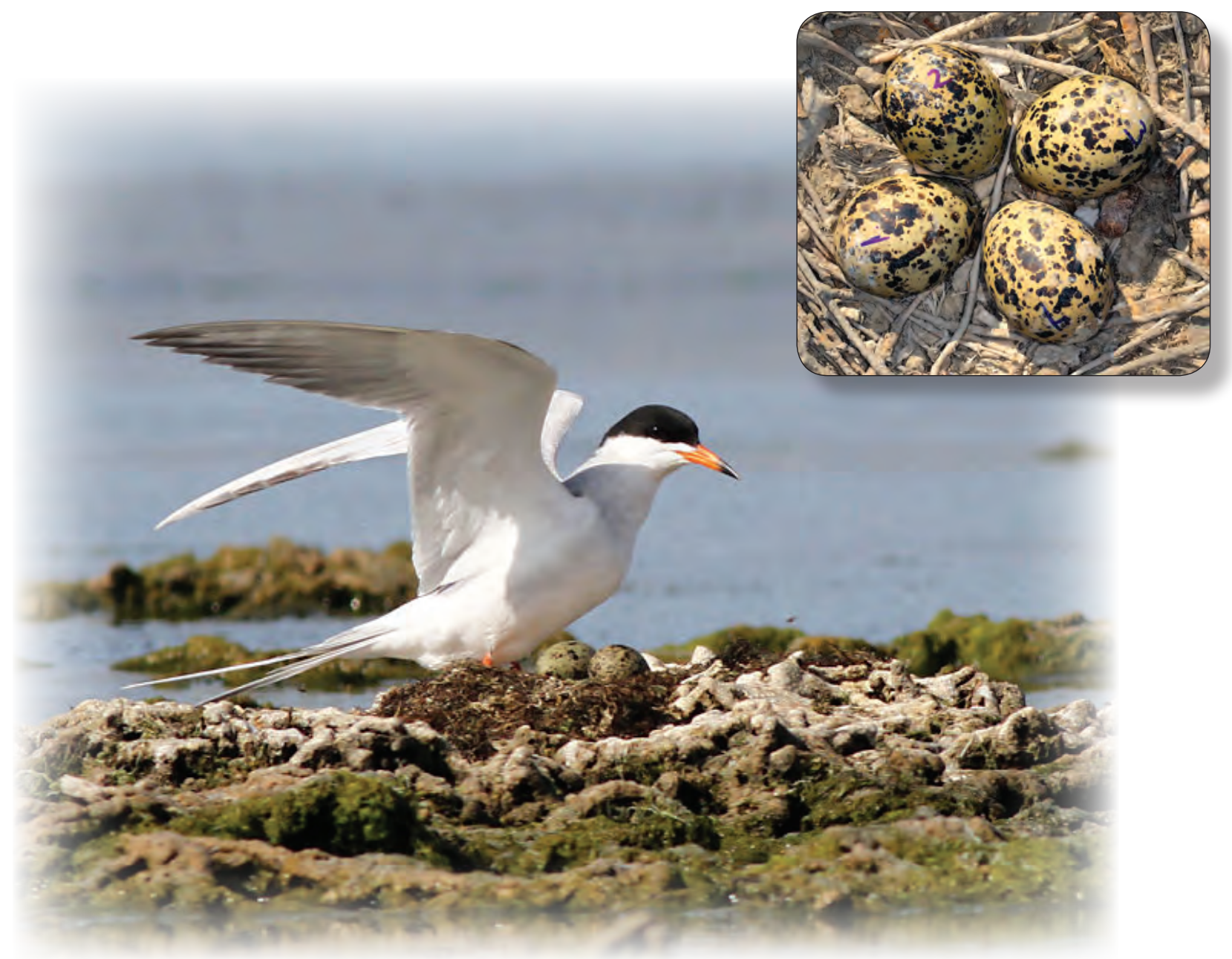

Open-File Report 2014-1189 
Cover: Bird photograph by Abe Borker, 2010. Egg photograph by Michael Kern, 2009. 


\section{Waterbird Egg Mercury Concentrations in Response to Wetland Restoration in South San Francisco Bay, California}

By Josh T. Ackerman, Mark P. Herzog, C. Alex Hartman, Trevor Watts, and Jarred Barr

Open-File Report 2014-1189

U.S. Department of the Interior

U.S. Geological Survey 


\section{U.S. Department of the Interior \\ SALLY JEWELL, Secretary}

\section{U.S. Geological Survey \\ Suzette M. Kimball, Acting Director}

U.S. Geological Survey, Reston, Virginia: 2014

For more information on the USGS-the Federal source for science about the Earth,

its natural and living resources, natural hazards, and the environment-visit

http://www.usgs.gov or call 1-888-ASK-USGS

For an overview of USGS information products, including maps, imagery, and publications, visit $h$ ttp://www.usgs.gov/pubprod

To order this and other USGS information products, visit http://store.usgs.gov

Suggested citation:

Ackerman, J.T., Herzog, M.P., Hartman, C.A., Watts, T., and Barr, J., 2014, Waterbird egg mercury concentrations in response to wetland restoration in south San Francisco Bay, California: U.S. Geological Survey Open-File Report 2014-1189, 22 p., http://dx.doi.org/10.3133/ofr20141189.

ISSN 2331-1258 (online)

Any use of trade, firm, or product names is for descriptive purposes only and does not imply endorsement by the U.S. Government.

Although this information product, for the most part, is in the public domain, it also may contain copyrighted materials as noted in the text. Permission to reproduce copyrighted items must be secured from the copyright owner. 


\section{Contents}

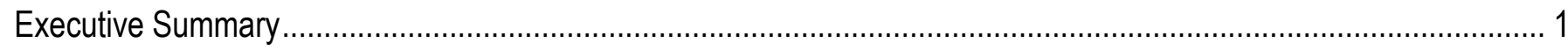

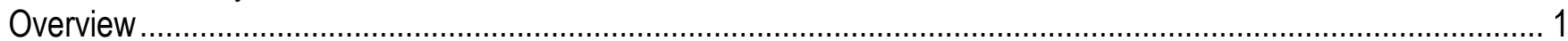

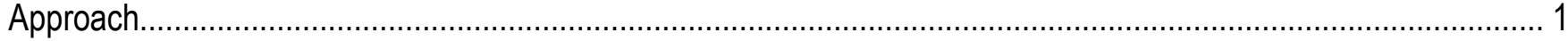

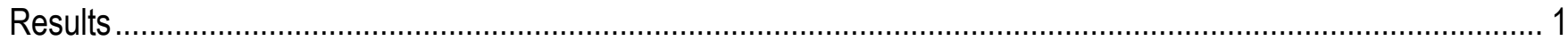

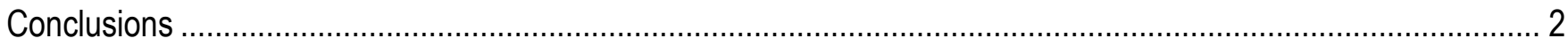

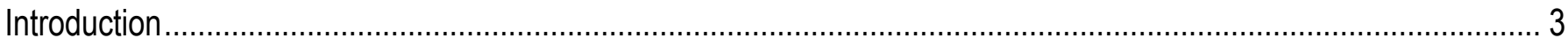

Study Area

Methods

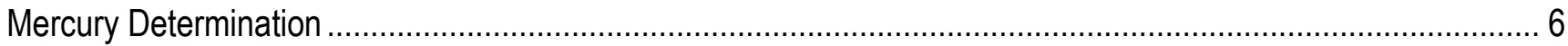

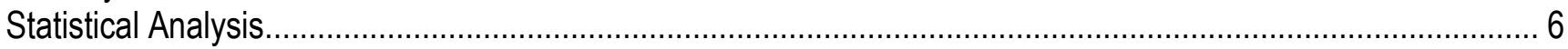

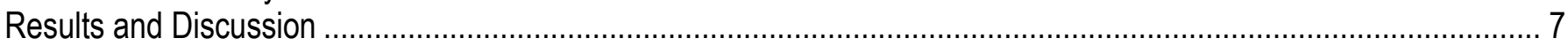

American Avocets (Recurvirostra americana) ........................................................................................

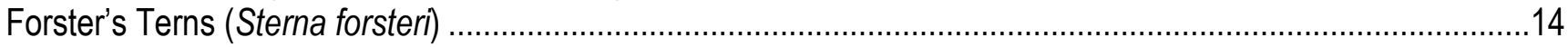

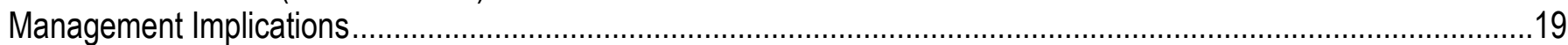

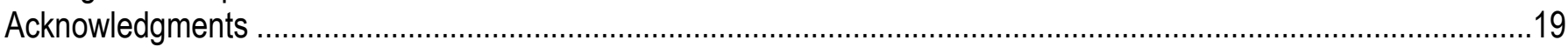

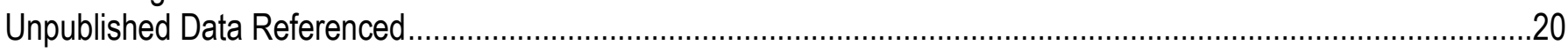

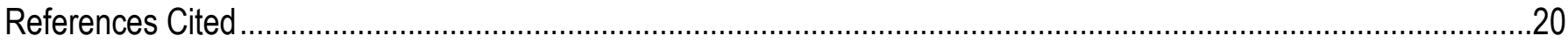

\section{Figures}

Figure 1. Locations of all American Avocet (Recurvirostra americana) and Forster's Tern (Sterna forsteri) eggs collected for this study, south San Francisco Bay, California, during the 2010, 2011, and 2013 nesting seasons ........ 5 Figure 2. Pond site and year differences in egg total mercury ( $\mathrm{THg}$ ) concentrations (in micrograms per gram fresh wet weight, $\mu \mathrm{g} / \mathrm{g}$ fww) for American Avocets (Recurvirostra americana) nesting in South Bay Salt Pond Restoration Project area, south San Francisco Bay, California

Figure 3. Total mercury (THg) concentrations (in micrograms per gram fresh wet weight, $\mu \mathrm{g} / \mathrm{g}$ fww) in American Avocet (Recurvirostra americana) eggs by date in South Bay Salt Pond Restoration Project area before (2010, blue dots) and after (2011, red dots; 2013, green dots) management activities associated with restoration of Pond A8/A7/A5 Complex, south San Francisco Bay, California, autumn 2010-spring 2011

Figure 4. Model-averaged mean and 95-percent credible intervals for total mercury $(\mathrm{THg})$ concentrations (in micrograms per gram fresh wet weight, $\mu \mathrm{g} / \mathrm{g} \mathrm{fww}$ ) in American Avocet (Recurvirostra americana) eggs in South Bay Salt Pond Restoration Project area before (2010) and after (2011 and 2013) management activities associated with restoration of Pond A8/A7/A5 Complex, south San Francisco Bay ,California, autumn 2010-spring 2011.

Figure 5. Pond site and year differences in egg total mercury $(\mathrm{THg})$ concentrations (in micrograms per gram fresh wet weight, $\mu \mathrm{g} / \mathrm{g}$ fww) for Forster's Terns (Sterna forsteri) nesting in South Bay Salt Pond Restoration Project area, south San Francisco Bay, California.

Figure 6. Total mercury (THg) concentrations (in micrograms per gram fresh wet weight, $\mu \mathrm{g} / \mathrm{g}$ fww) in Forster's Tern (Sterna forsteri) eggs by date in South Bay Salt Pond Restoration Project area before (2010, blue dots) and after (2011, red dots; 2013, green dots) management activities associated with restoration of Pond A8/A7/A5 Complex, south San Francisco Bay, California, autumn 2010-spring 2011

Figure 7. Model-averaged mean and 95-percent credible intervals for total mercury $(\mathrm{THg})$ concentrations (in micrograms per gram fresh wet weight, $\mu \mathrm{g} / \mathrm{g}$ fww) in Forster's Tern (Sterna forsteri) eggs in South Bay Salt Pond Restoration Project area before (2010) and after (2011 and 2013) management activities associated with restoration of Pond A8/A7/A5 Complex, south San Francisco Bay ,California, autumn 2010-spring 2011 


\section{Tables}

Table 1. Egg total mercury concentrations for Forster's Terns (Sterna forsteri) and American Avocets (Recurvirostra americana) nesting in South Bay Salt Pond Restoration Project area before (2010) and after (2011 and 2013) management activities associated with restoration of the Pond A8/A7/A5 Complex, south San Francisco Bay, California, autumn 2010-spring 2011

Table 2. Model selection results for egg total mercury concentrations (in micrograms per gram fresh wet weight ) in American Avocets (Recurvirostra americana) nesting in South Bay Salt Pond Restoration Project area before (2010) and after (2011 and 2013) management activities associated with restoration of Pond A8/A7/A5 Complex, south San Francisco Bay, California, autumn 2010-spring 2011

Table 3. Model selection results for egg total mercury concentrations micrograms per gram fresh wet weight) in Forster's Terns (Sterna forsteri) nesting in South Bay Salt Pond Restoration Project area before (2010) and after (2011 and 2013) management activities associated with restoration of the Pond A8/A7/A5 Complex, south San Francisco Bay, California, autumn 2010-spring 2011

\section{Conversion Factors, and Abbreviations and Acronyms}

\section{Conversion Factors}

Inch/Pound to SI

\begin{tabular}{lcl}
\hline & \multicolumn{1}{c}{ Bultiply } & \multicolumn{1}{c}{ To obtain } \\
\hline foot $(\mathrm{ft})$ & Length & \\
\hline & 0.3048 & meter $(\mathrm{m})$ \\
\hline acre & Area & \\
acre & 4,047 & square meter $\left(\mathrm{m}^{2}\right)$ \\
\hline
\end{tabular}

SI to Inch/Pound

\begin{tabular}{|c|c|c|}
\hline Multiply & By & To obtain \\
\hline \multicolumn{3}{|c|}{ Mass } \\
\hline gram (g) & 0.03527 & ounce, avoirdupois (oz) \\
\hline microgram $(\mu \mathrm{g})$ & 0.00000003527 & ounce, avoirdupois (oz) \\
\hline
\end{tabular}

Temperature in degrees Celsius $\left({ }^{\circ} \mathrm{C}\right)$ may be converted to degrees Fahrenheit $\left({ }^{\circ} \mathrm{F}\right)$ as follows:

${ }^{\circ} \mathrm{F}=\left(1.8 x^{\circ} \mathrm{C}\right)+32$

\section{Abbreviations and Acronyms}

$\begin{array}{ll}\text { AIC } & \text { Akaike's Information Criterion } \\ \mathrm{dw} & \text { dry weight } \\ \mathrm{ww} & \text { wet weight } \\ \mathrm{fww} & \text { fresh wet weight } \\ \mathrm{Hg} & \text { mercury } \\ \mathrm{THg} & \text { total mercury } \\ \mathrm{MeHg} & \text { methylmercury } \\ \mathrm{NCM} & \text { New Chicago Marsh } \\ \text { USGS } & \text { U.S. Geological Survey }\end{array}$




\section{Waterbird Egg Mercury Concentrations in Response to Wetland Restoration in South San Francisco Bay, California}

By Josh T. Ackerman, Mark P. Herzog, Alex Hartman, Trevor Watts, and Jarred Barr

\section{Executive Summary}

\section{Overview}

- The conversion of 50-90 percent of 15,100 acres of former salt evaporation ponds to tidal marsh habitat in the south San Francisco Bay, California, is planned as part of the South Bay Salt Pond Restoration Project. This large-scale habitat restoration may change the bioavailability of methylmercury. The South Bay already is known to have high methylmercury concentrations, with methylmercury concentrations in several waterbirds species more than known toxicity thresholds where avian reproduction is impaired.

- In this 2013 study, we continued monitoring bird egg mercury concentrations in response to the restoration of the Pond A8/A7/A5 Complex to a potential tidal marsh in the future. The restoration of the Pond A8/A7/A5 Complex began in autumn 2010, and the Pond A8 Notch was opened 5 feet (one of eight gates) to muted tidal action on June 1, 2011, and then closed in the winter. In autumn 2010, internal levees between Ponds A8, A7, and A5 were breached and water depths were substantially increased by flooding the Pond A8/A7/A5 Complex in February 2011. In June 2012, 15 feet (three of eight gates) of the Pond A8 Notch was opened, and then closed in December 2012. In June 2013, 15 feet of the Pond A8 Notch again was opened, and the Pond A8/A7/A5 Complex was a relatively deep and large pond with muted tidal action in the summer.

- This report synthesizes waterbird data from the 2013 breeding season, and combines it with our prior study's data from 2010 and 2011.

\section{Approach}

- We tested the effect of the Pond A8 restoration project by examining changes in waterbird egg mercury concentrations over time (2010, 2011, and 2013) at the Restored Ponds (Pond A8/A7/A5 Complex) in relation to Reference Ponds that were outside the restoration area.

\section{Results}

- We sampled 60 Forster's Tern (Sterna forsteri) and 60 American Avocet (Recurvirostra americana) (hereafter referred to as "Tern" and "Avocet," respectively) eggs during the 2013 study. Together with our historical dataset from 2010 and 2011, the total sample size of eggs included in this report was 180 Tern and 224 Avocet eggs. 
- Egg mercury concentrations averaged 1.63 micrograms per gram fresh wet weight ( $\mu \mathrm{g} / \mathrm{g}$ fww; range of $0.44-7.33 \mu \mathrm{g} / \mathrm{g}$ fww) in Terns and $0.32 \mu \mathrm{g} / \mathrm{g}$ fww (range of $0.02-1.99 \mu \mathrm{g} / \mathrm{g}$ fww) in Avocets across all 3 years.

- Mercury concentrations in Tern eggs increased by 69 percent between 2010 and 2011 at the Restored Ponds after the restoration actions, compared to a slight decrease in Tern egg mercury concentrations (10 percent) between years at the Reference Ponds.

- Between 2011 and 2013, Tern egg mercury concentrations decreased by 59 percent at the Restored Ponds, compared to a decrease of 23 percent at the Reference Ponds.

- The end result of this 3-year comparison was that Tern egg mercury concentrations decreased between 2010 and 2013 by 31 percent at both the Restored and Reference Ponds.

- Avocet egg mercury concentrations in Restored Ponds followed a pattern similar to the concentration trajectory for the Reference Ponds, with egg mercury concentrations decreasing by 4 percent between 2010 and 2011, and further decreasing by about 40 percent between 2011 and 2013. The end result was that Avocet egg mercury concentrations decreased between 2010 and 2013 by 42 percent at the Restored Ponds and 43 percent at the Reference Ponds.

- Regardless of the changes between years, Avocet egg mercury concentrations in the Restored Ponds still were 92 percent higher than concentrations in the Reference Ponds in 2013, similar to 2010 baseline conditions where mercury concentrations in the Restored Ponds were 87 percent higher than concentrations in the Reference Ponds. Similarly, Tern egg mercury concentrations in Restored Ponds were 6 percent higher than concentrations in the Reference Ponds in 2013, similar to 2010 baseline conditions where mercury concentrations in the Restored Ponds were 7 percent higher than concentrations in the Reference Ponds.

- In the Restored Ponds in 2013, most Tern egg mercury concentrations (70 percent) and a smaller percentage of Avocet egg mercury concentrations (11 percent) still remained higher than concentrations associated with reproductive impairment $(>0.90 \mu \mathrm{g} / \mathrm{g}$ fww). For reference, 90 percent and 100 percent of Tern eggs in the Restored Ponds exceeded this threshold in 2010 and 2011, respectively.

\section{Conclusions}

- Despite the significant increase (2010-2011) and correspondingly large decrease (2011-2013) in Tern egg mercury concentrations at the Restored Ponds, both Tern and Avocet egg mercury concentrations in the Restored Ponds still are similar to concentrations that would have been expected without the restoration actions.

- Ambient egg mercury concentrations within the south San Francisco Bay have decreased since 2010, but the restoration actions apparently did not change the baseline trajectory of egg mercury concentrations within the Restored Ponds. In particular, Ponds A7 and A8 still are mercury "hotspots" for both Tern and Avocet eggs compared to other ponds in 2013, even though it has been 2 years since most construction activities have ceased and the Pond A8/A7/A5 Complex has been opened to the flow of bay water. 
- It will be important to document if egg mercury concentrations continue to decrease in the future as the Restored Ponds continue to develop, the Pond A8 Notch is opened for more of the year, the gates are opened earlier (March 6 in 2014), and more gates are opened (currently [2014] only three of eight gates are being opened). With further decreases in egg mercury concentrations relative to the Reference Ponds, the Restored Ponds possibly could attain lower egg mercury concentrations than would have been expected without any restoration actions, but, as of 2013, this goal for the South Bay Salt Pond Restoration Project has not been met.

- Continued monitoring of waterbird egg mercury concentrations in the restoration project area, relative to reference sites, is warranted over a period of multiple years, given the large fluctuations in waterbird egg mercury concentrations observed in these studies.

- The data indicate that the South Bay Salt Pond Restoration Project develop and implement a longterm monitoring strategy for methylmercury exposure to nesting waterbirds at several project sites. This monitoring network could build on the existing and robust dataset of methylmercury concentrations in eggs of key waterbird species that breed within the South Bay Salt Pond Restoration Project boundaries, including Forster's Terns, American Avocets, and Black-necked Stilts (Himantopus mexicanus). These data would allow restoration managers to document changes in methylmercury bioaccumulation in taxa most sensitive to methylmercury exposure and would guide multiple restoration actions occurring at several sites within the region.

\section{Introduction}

Two of the most significant anthropogenic changes in the San Francisco Bay estuary over the past 150 years are the loss of more than 85 percent of fringing tidal wetlands (Goals Project, 1999) and the contamination of the estuarine food web with mercury $(\mathrm{Hg})$. These effects are particularly pronounced in the South San Francisco Bay (South Bay), which, historically, was fringed with extensive tidal marshes and which receives drainage from New Almaden, the largest historic Hg mine in North America. Extensive wetland restoration in the South Bay aims to return tidal marshes and the important ecosystem function that these wetlands provided. However, high rates of methylmercury $(\mathrm{MeHg}$, the most toxic and bioaccumulative form of $\mathrm{Hg}$ ) production, export, and bioaccumulation have been associated with wetlands relative to other water bodies (Hurley and others, 1995; Krabbenhoft and others, 1999; Waldron and others, 2000; Marvin-DiPasquale and others, 2003). Therefore, Hg bioavailability potentially could increase in the South Bay as former salt ponds are restored to tidal marsh and other habitats that receive bay water during parts of the year. This is a particularly important concern, because $\mathrm{Hg}$ concentrations in tissues and eggs of birds in the South Bay exceed toxicological thresholds (Ackerman and Eagles-Smith, 2008, unpublished), and there is evidence that $\mathrm{Hg}$ may be impairing egg hatchability, chick survival, and body condition of birds in San Francisco Bay (Ackerman and Eagles-Smith, 2008, unpublished; Ackerman and others, 2008a, 2012a). Thus, any increase in $\mathrm{MeHg}$ production and subsequent bioaccumulation in waterbirds may further impair bird reproduction, as well as other wildlife and associated human health risks. 
For the South Bay Salt Pond Restoration Project, one of the first major restoration management actions was the breaching of the internal levees that separated Ponds A5, A7, and A8, which was done during the winter of 2010-11 in preparation for restoring muted tidal action to the newly formed Restored Ponds A8, A7, and A5 (hereafter referred to as "the A8/A7/A5 Complex"), beginning on June 1, 2011. Tidal exchange was facilitated by the construction of an adjustable 40-ft-wide weir-like notch in the southeastern corner of Pond A8 (A8 Notch), which reconnects hydrologic flow between the A8/A7/A5 Complex and Alviso Slough for 6 months of the year (about June 1-November 30), with the A8 Notch closed during the remainder of the year because of permit restrictions to protect anadramous fish. Concerns about the construction of the A8 Notch and the opening of the A8/A7/A5 Complex include sediment scour and redistribution of $\mathrm{Hg}$ in adjacent Alviso Slough (where total mercury [THg] concentrations in sediments were 3 times higher than in the greater South Bay; Marvin-DiPasquale and Cox, 2007), and potential changes to $\mathrm{MeHg}$ biomagnification in the A8/A5/A7 Complex, Alviso Slough, and the larger South Bay Salt Pond Restoration Project area.

In Pond A8, MeHg concentrations in the biota and sediments are among the highest of any measured in wetlands in the entire South Bay (Ackerman and others, 2007a, 2007b, unpublished; Ackerman and Eagles-Smith, 2008, unpublished; Miles and Ricca, 2010; Ackerman and others, 2012b, unpublished, 2013a, unpublished). It is unclear how Hg cycling within the A8/A5/A7 Complex will progress with the periodic opening and operation of the Pond A8 Notch.

During the initial study of the Pond A8 restoration, Ackerman and others (2013a, unpublished) noted that egg mercury concentrations in the Forster's Tern (Sterna forsteri, hereafter referred to as "Tern") increased substantially between 2010 and 2011 at Restored Ponds A8 and A7 (an average increase of 74 percent or $1.22 \mu \mathrm{g} / \mathrm{g}$ fww), but were similar between years at Reference Ponds A1 and A2W outside of the restoration area (change of -9 percent or $-0.04 \mu \mathrm{g} / \mathrm{g}$ fww). For American Avocets (Recurvirostra americana, hereafter referred to as "Avocets"), the change in egg mercury concentrations between years in Restored Ponds ( -3 percent or $-0.011 \mu \mathrm{g} / \mathrm{g}$ fww), relative to Reference Ponds (-0.4 percent or $-0.008 \mu \mathrm{g} / \mathrm{g}$ fww), was small. After the restoration activities, 100 percent of Tern eggs and 14 percent of Avocet eggs within Restored Ponds A7 and A8 exceeded the $0.90-\mu \mathrm{g} / \mathrm{g}$ fww toxicity threshold. Similarly, the restoration activities between 2010 and 2011 increased mercury concentrations in fish in the Restored Pond A8/A7/A5 Complex relative to ambient mercury concentrations in the Reference Ponds.

These increased mercury concentrations in biota occurred in the year immediately following the construction actions and initial opening, but it was uncertain whether high mercury concentrations in bird eggs would continue in the Pond A8/A7/A5 Complex as this restored habitat was further developed and the Pond A8 Notch was widened further. The authors suggested that the South Bay Salt Pond Restoration Project should develop and implement a long-term monitoring strategy for methylmercury exposure to nesting waterbirds to document changes in bird-egg mercury concentrations in the Pond A8 restoration project as well as throughout the South Bay Salt Pond Restoration Project area as other restoration and enhancement projects are constructed. Therefore, the South Bay Salt Pond Restoration Project, U.S. Environmental Protection Agency, and State of California Coastal Conservancy funded the U.S. Geological Survey in 2013, 2 years after the Pond A8 Notch was opened, to document near-term trends in waterbird egg mercury concentrations. 


\section{Study Area}

Within the South Bay Salt Pond Restoration Project boundaries, the main study sites were within the Don Edwards San Francisco Bay National Wildlife Refuge and Eden Landing Ecological Reserve (fig. 1). The study focused on the Pond A8/A7/A5 Complex and Reference Ponds A1, A2W, AB1, N4/N5, E2, SF2, and New Chicago Marsh (NCM). Reference sites were critical to assess baseline "ambient" Hg bioaccumulation that was not associated with the restoration activities that occurred in the Pond A8/A7/A5 Complex.
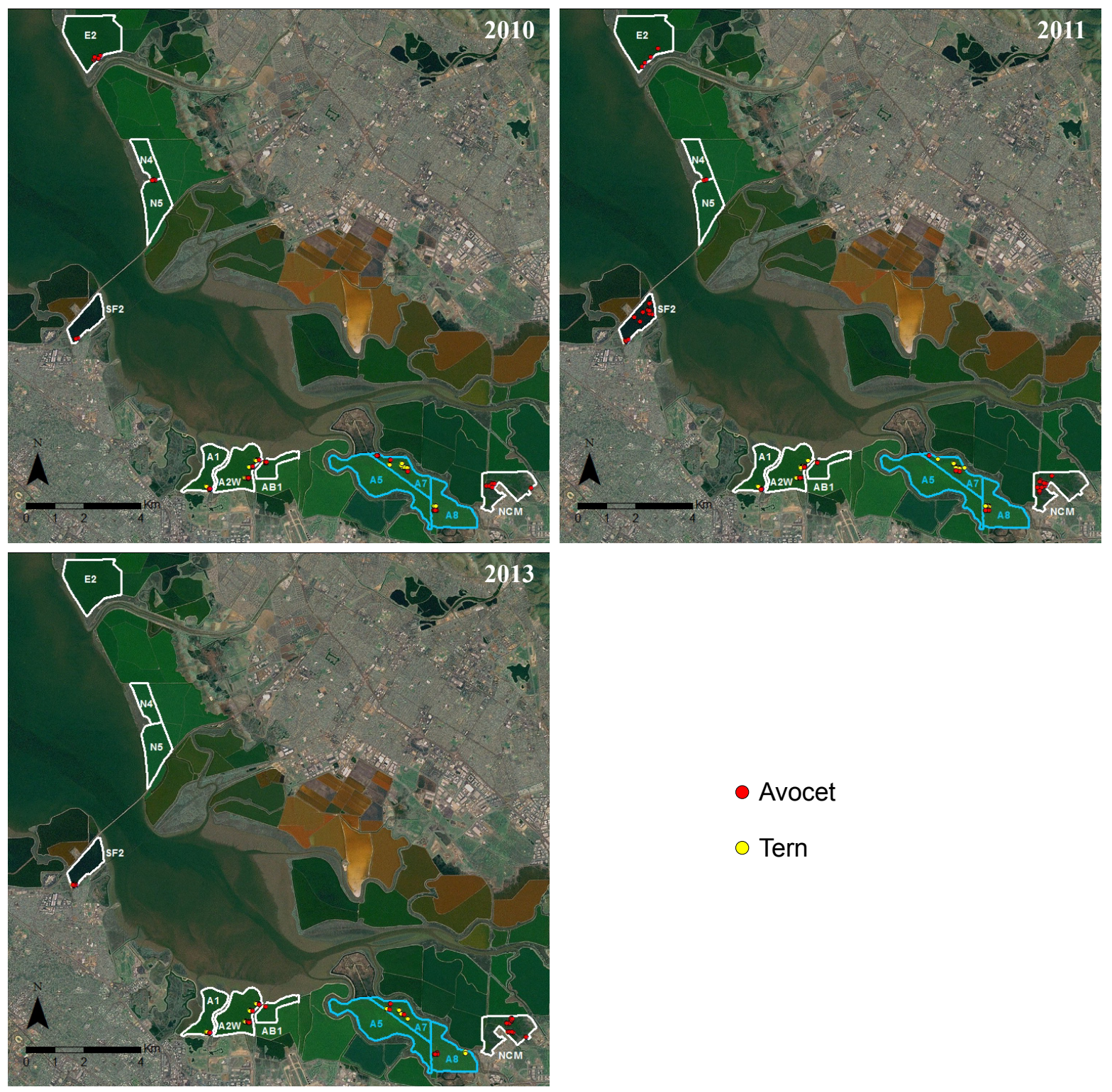

- Avocet

$\circ$ Tern

Figure 1. Locations of all American Avocet (Recurvirostra americana) and Forster's Tern (Sterna forsteri) eggs collected for this study, south San Francisco Bay, California, during the 2010, 2011, and 2013 nesting seasons. Restored Ponds A8, A7, and A5 are highlighted in blue. Reference Ponds A1, A2W, AB1, N4/5, E2, SF2, and New Chicago Marsh (NCM) are highlighted in white. 


\section{Methods}

We monitored $\mathrm{MeHg}$ concentrations in randomly collected Tern and Avocet eggs at more than four colonies per species per year in 2010, 2011, and 2013 (fig. 1). Colony locations for Tern and Avocet egg collections were selected to include two primary nesting colonies in the restored area (Ponds A8 and A7) and two nesting colonies outside of the immediate vicinity of the Pond A8 restoration area to act as reference sites (Ponds A1 and A2W in the Moffett Salt Pond Complex). For Avocets, reference nesting colonies also were included in five additional pond units (NCM and Ponds AB1, E2 [not in 2013], N4/N5 [not in 2013], and SF2). We randomly sampled one egg from as many as 15 nests per colony for each species during the 2010, 2011, and 2013 nesting seasons. We refrigerated collected eggs until laboratory processing, at which time we measured egg size and volume, dissected and opened each egg, removed all egg contents and placed them in a polypropylene jar, and froze the egg at $-20{ }^{\circ} \mathrm{C}$ until THg analysis.

\section{Mercury Determination}

The mean percentage of THg in the MeHg form in bird eggs is 96 percent (Ackerman and others, 2013b); therefore, $\mathrm{THg}$ concentrations were used to estimate MeHg concentrations in bird eggs. We processed and analyzed all egg samples for THg at the U.S. Geological Survey, Dixon Field Station Environmental Mercury Laboratory, using a Milestone DMA-80 Direct THg Analyzer (Milestone Inc., Shelton, Connecticut) following U.S. Environmental Protection Agency Method 7473 (U.S.

Environmental Protection Agency, 2000). THg concentrations in eggs were determined on a dry-weight basis and then converted to a fresh wet weight egg concentration using egg moisture content and a species-specific egg volume and egg density coefficient developed by J.T. Ackerman (U.S. Geological Survey, unpub. data, 2009). Quality-assurance measures included analysis of two certified reference materials (either dogfish muscle tissue [DORM-3 or DORM-4], dogfish liver [DOLT-3 or DOLT-4], or lobster hepatopancreas [TORT-2 or TORT-3] by the National Research Council of Canada, Ottawa), two system and method blanks, three continuing calibration verifications, and two duplicates per batch. Recoveries (mean \pm SE) were $101.2 \pm 0.5$ percent $(N=125)$ for certified reference materials, $98.7 \pm 0.4$ percent $(N=178)$ for calibration verifications, and $96.9 \pm 0.5$ percent $(N=87)$ for matrix spikes. Absolute relative percent differences were $2.8 \pm 0.3$ percent $(N=111)$ for duplicates and $2.1 \pm 0.3$ percent $(N=43)$ for matrix spike duplicates.

\section{Statistical Analysis}

To test for changes in egg $\mathrm{THg}$ concentrations associated with restoration actions in the Pond A8/A7/A5 Complex, we performed linear mixed modeling (Pinheiro and Bates, 2000) to test for differences among wetlands and years for Terns and Avocets. Each species was analyzed separately and egg THg concentrations were log-transformed prior to analyses.

For Terns and Avocets, we tested the effects of the restoration actions by examining the differences in egg THg concentrations between (1) Restored Ponds and Reference Ponds, and (2) among years (2010, 2011, and 2013). In addition to Pond Type (Restored Ponds compared to Reference Ponds) and Year, we also included Nest Initiation Date (standardized as day of the year), the quadratic form of Date (Date ${ }^{2}$; for example, Eagles-Smith and Ackerman, 2009), and all two-way interactions (Pond Type $\times$ Year, Pond Type $\times$ Date, Year $\times$ Date), yielding a total of 31 models including the null model 
(intercept and variance only). We did not include the Before or After the Pond A8 Notch opening test because we did not find it to be important for THg concentrations in Tern eggs in 2010 and 2011, and, in 2013, few data were available after the Pond A8 Notch was opened. We used 180 Tern and 224 Avocet eggs in the modeling effort. In all models, we incorporated pond site (pond identification) as a random effect. We assessed model performance using model inference and Akaike's Information Criterion (specifically, the second-order metric, AICc; Burnham and Anderson, 2002).

All predictions are model-averaged predictions, based on 1,000 simulations of each model weighted by the AICc weight of each model. The overall mean is the mean of these 1,000 simulations. We also present 90 percent credible intervals (hereafter referred to as " 90 percent CI") between the 5 th and 95th percentiles of the 1,000 simulations. We then backtransformed the results to provide estimates within the same scale as the observed data.

\section{Results and Discussion}

We sampled 60 Forster's Tern and 60 American Avocet eggs during this 2013 study. Together with the historical dataset from 2010 and 2011 (Ackerman and others, 2012b, unpublished, 2013a, unpublished), the total sample size of eggs included in this report was 180 Tern and 224 Avocet eggs. We monitored $\mathrm{THg}$ concentrations in as many as 15 randomly collected Tern and Avocet eggs from four or more nesting colonies per species, including Ponds A8 and A7 in the restoration area, as well as Reference Ponds outside of the immediate restoration area (fig. 1).

\section{American Avocets (Recurvirostra americana)}

Across all ponds and years, egg THg concentrations in Avocets ranged from 0.02 to $1.99 \mu \mathrm{g} / \mathrm{g}$ fww, with a mean of $0.32 \mu \mathrm{g} / \mathrm{g}$ fww $(N=224$ eggs; table 1$)$. Overall, 3 percent of randomly sampled Avocet eggs in 2013 exceeded the $0.90 \mu \mathrm{g} / \mathrm{g}$ fww toxicity threshold developed for Forster's Terns in San Francisco Bay (Ackerman and Eagles-Smith, 2008, unpublished).

The most parsimonious model describing Avocet egg THg concentrations included pond type, year, date, and the year $\times$ date interaction, and had an Akaike weight of 0.24 (table 2). Three other models containing year, date, and the year $\times$ date interaction plus either date ${ }^{2}$, pond type, or pond type $\times$ date interaction had a change in $\mathrm{AIC} c$ value of less than or equal to 2.0 from that of the most parsimonious model ( $\triangle \mathrm{AIC} c \leq 2.0$; table 2 ). All models containing year, date, pond type, and the year $\times$ date had a cumulative Akaike weight of 0.65 . We estimated the relative importance of individual variables (calculated as the sum of all model weights where the variable was present) and determined that the data strongly supported effects of year (relative variable importance $=1.00)$, date $(0.95)$, and the year $\times$ date interaction (0.87). Pond type (0.75) had a moderate level of support, and date ${ }^{2}(0.35)$, pond type $\times$ date interaction $(0.25)$, and pond type $\times$ year interaction $(0.11)$ had little support. To further 
determine the importance of variables in the best model, we compared the best model to the same model structure, but omitted one of the variables of interest. Using this evidence-ratio approach, we estimated that the best model that included year was 14,673 times more likely than the same model without year. Similarly, the best model was 8.7 times more likely than the same model but without the date variable and 1.7 times more likely than the same model but without the pond type variable. The arithmetic mean of egg THg concentrations for Avocets by year for each pond is shown in figure 2. The raw and modelpredicted (partial residual, which statistically accounts for the other variables in the model) egg $\mathrm{THg}$ concentrations for each Avocet egg by date for Reference and Restored Ponds is shown in figure 3. Model-predicted (at mean nest initiation day of year=129) mean egg $\mathrm{THg}$ concentrations in Avocets decreased by 4 percent between 2010 and 2011 at Restored Ponds (2010, $0.35 \mu \mathrm{g} / \mathrm{g}$ fww; 2011, $0.33 \mu \mathrm{g} / \mathrm{g}$ fww), and also decreased slightly by 4 percent between years at Reference Ponds $(2010,0.19$ $\mu \mathrm{g} / \mathrm{g}$ fww; 2011, $0.18 \mu \mathrm{g} / \mathrm{g}$ fww (fig. 4). Thereafter, mean egg THg concentrations in Avocets decreased by 39 percent between 2011 and 2013 at Restored Ponds (2011, $0.33 \mu \mathrm{g} / \mathrm{g} \mathrm{fww;} \mathrm{2013,0.20} \mu \mathrm{g} / \mathrm{g} \mathrm{fww}$ ), and decreased by 40 percent between years at

Reference Ponds (2011, $0.18 \mu \mathrm{g} / \mathrm{g}$ fww; 2013, $0.11 \mu \mathrm{g} / \mathrm{g}$ fww) (fig. 4). The end result of this 3-year comparison was that model-predicted mean egg THg concentrations in Avocets decreased between 2010 and 2013 by 42 percent at Restored Ponds and by 43 percent at Reference Ponds (fig. 4). Mean Avocet egg THg concentrations in the Restored Ponds still were 92 percent higher than concentrations in the Reference Ponds in 2013 (Restored Ponds, $0.20 \mu \mathrm{g} / \mathrm{g}$ fww; Reference Ponds, 0.11 $\mu \mathrm{g} / \mathrm{g}$ fww), similar to 2010 baseline THg concentration differences where Restored Ponds were 87 percent higher than Reference Ponds (Restored Ponds, $0.35 \mu \mathrm{g} / \mathrm{g}$ fww; Reference Ponds, $0.19 \mu \mathrm{g} / \mathrm{g}$ fww) (fig. 4). Pond-specific percent changes in the arithmetic means of Avocet egg THg concentrations, based on raw data, are shown in table 1.

Therefore, the restoration project has not changed the baseline $\mathrm{Hg}$ concentration trajectory in Avocet eggs at the Restored Ponds, and Ponds A7 and A8 still were considered to be $\mathrm{Hg}$ "hotspots" for Avocet eggs in 2013, similar to the finding of our prior research (Ackerman and others, 2007a, 2007b, unpublished, 2008a). For example, the arithmetic mean of Avocet egg THg concentrations in Restored Pond A8 was $0.57 \mu \mathrm{g} / \mathrm{g}$ fww in 2013, which is 420 percent higher than the highest primary reference site mean THg concentration in Avocet eggs at Pond A2W (0.11 $\mu \mathrm{g} / \mathrm{g}$ fww; table 1$)$. Moreover, 11 percent of Avocet egg Hg concentrations in the Restored Ponds in 2013 were higher than concentrations associated with reproductive impairment. Importantly, New Chicago Marsh (NCM), another highly contaminated site, also showed substantial decreases in egg $\mathrm{THg}$ concentrations in 2013. 
Table 1. Egg total mercury concentrations for Forster's Terns (Sterna forsteri) and American Avocets (Recurvirostra americana) nesting in South Bay Salt Pond Restoration Project area before (2010) and after (2011 and 2013) management activities associated with restoration of the Pond A8/A7/A5 Complex, south San Francisco Bay, California, autumn 2010-spring 2011.

[Restored Ponds included Ponds A7 and A8. Reference Ponds included Ponds A1, A2W, AB1, E2, N4/5, SF2, and New Chicago Marsh. Abbreviations: SD, standard deviation; Min, minimum; Max, maximum; \% THG, percent total mercury; $\mu \mathrm{g} / \mathrm{g}$ fww, micrograms per gram fresh wet weight (mercury concentrations); -, no data]

Forster's Tern

\begin{tabular}{|c|c|c|c|c|c|c|c|c|c|c|c|c|c|c|c|c|c|c|c|}
\hline Site & Year & $\begin{array}{c}\text { Number } \\
\text { of Eggs }\end{array}$ & $\begin{array}{c}\text { Arithmetic } \\
\text { mean } \\
(\mu \mathrm{g} / \mathrm{g} \text { fww })\end{array}$ & $\begin{array}{l}\text { SD } \\
(\mu g / g \\
\text { fww })\end{array}$ & $\begin{array}{l}\text { Min } \\
(\mu \mathrm{g} / \mathrm{g} \\
\mathrm{fww}) \\
\end{array}$ & $\begin{array}{l}\text { Max } \\
(\mu \mathrm{g} / \mathrm{g} \\
\mathrm{fww}) \\
\end{array}$ & $\begin{array}{c}\text { THg } \\
\text { change } \\
(2011- \\
2010) \\
\end{array}$ & $\begin{array}{c}\text { THg change } \\
(2011-2010 \mu \mathrm{g} / \mathrm{g} \\
\text { fww) }\end{array}$ & $\begin{array}{c}\text { THg } \\
\text { change } \\
(2013- \\
2011) \\
\end{array}$ & $\begin{array}{c}\text { THg } \\
\text { change } \\
(2013- \\
2011 \mu \mathrm{g} / \mathrm{g} \\
\text { fww) }\end{array}$ & $\begin{array}{c}\text { Number } \\
\text { of Eggs }\end{array}$ & $\begin{array}{l}\text { Arithmetic } \\
\text { mean } \\
(\mu \mathrm{g} / \mathrm{g} \text { fww })\end{array}$ & $\begin{array}{l}\text { SD } \\
(\mu g / g \\
\text { fww }) \\
\end{array}$ & $\begin{array}{l}\text { Min } \\
(\mu \mathrm{g} / \mathrm{g} \\
\text { fww) }\end{array}$ & $\begin{array}{l}\text { Max } \\
(\mu \mathrm{g} / \mathrm{g} \\
\mathrm{fww}) \\
\end{array}$ & $\begin{array}{c}\text { THg } \\
\text { change } \\
(2011- \\
2010) \\
\end{array}$ & $\begin{array}{c}\text { THg } \\
\text { change } \\
(2011- \\
2010 \mu g / g \\
\text { fww) }\end{array}$ & $\begin{array}{c}\text { THg } \\
\text { change } \\
(2013- \\
2011) \\
\end{array}$ & $\begin{array}{c}\text { THg } \\
\text { change } \\
(2013-- \\
2011 \mu \mathrm{g} / \mathrm{g} \\
\text { fww) }\end{array}$ \\
\hline \multirow[t]{3}{*}{$\overline{\mathrm{A} 7}$} & 2010 & 15 & 1.74 & 0.67 & 0.82 & 2.77 & $+78 \%$ & +1.35 & $-57 \%$ & -1.76 & 7 & 0.50 & 0.18 & 0.30 & 0.81 & $+18 \%$ & +0.09 & $-41 \%$ & -0.24 \\
\hline & 2011 & 15 & 3.09 & 1.50 & 1.76 & 7.33 & & & & & 7 & 0.59 & 0.42 & 0.25 & 1.49 & & & & \\
\hline & 2013 & 15 & 1.33 & 0.47 & 0.63 & 2.29 & & & & & 5 & 0.35 & 0.16 & 0.10 & 0.50 & & & & \\
\hline \multirow[t]{3}{*}{$\overline{\mathrm{A} 8}$} & 2010 & 15 & 1.69 & 0.60 & 0.78 & 2.63 & $+66 \%$ & +1.11 & $-66 \%$ & -1.85 & 15 & 0.41 & 0.25 & 0.03 & 0.91 & $+16 \%$ & +0.07 & $+20 \%$ & +0.09 \\
\hline & 2011 & 15 & 2.80 & 0.87 & 1.64 & 4.45 & & & & & 15 & 0.48 & 0.44 & 0.08 & 1.72 & & & & \\
\hline & 2013 & 15 & 0.95 & 0.43 & 0.44 & 1.88 & & & & & 13 & 0.57 & 0.43 & 0.11 & 1.53 & & & & \\
\hline \multirow[t]{3}{*}{$\overline{\mathrm{A} 1}$} & 2010 & 15 & 1.51 & 0.51 & 0.80 & 2.39 & $-10 \%$ & -0.15 & $-33 \%$ & -0.45 & 14 & 0.13 & 0.06 & 0.05 & 0.24 & $+37 \%$ & +0.05 & $-53 \%$ & -0.09 \\
\hline & 2011 & 15 & 1.37 & 0.55 & 0.56 & 2.11 & & & & & 8 & 0.17 & 0.12 & 0.09 & 0.44 & & & & \\
\hline & 2013 & 15 & 0.92 & 0.31 & 0.46 & 1.71 & & & & & 4 & 0.08 & 0.02 & 0.07 & 0.11 & & & & \\
\hline \multirow[t]{3}{*}{$\overline{\mathrm{A} 2 \mathrm{~W}}$} & 2010 & 15 & 1.56 & 0.52 & 0.86 & 2.81 & $+8 \%$ & +0.13 & $-43 \%$ & -0.73 & 10 & 0.16 & 0.09 & 0.05 & 0.31 & $+58 \%$ & +0.09 & $-55 \%$ & -0.14 \\
\hline & 2011 & 15 & 1.70 & 0.59 & 0.92 & 3.24 & & & & & 15 & 0.25 & 0.48 & 0.06 & 1.97 & & & & \\
\hline & 2013 & 15 & 0.97 & 0.27 & 0.62 & 1.50 & & & & & 15 & 0.11 & 0.11 & 0.02 & 0.44 & & & & \\
\hline \multirow[t]{3}{*}{$\overline{\mathrm{AB} 1}$} & 2010 & - & - & - & - & - & - & - & - & - & 10 & 0.22 & 0.11 & 0.08 & 0.44 & $-62 \%$ & -0.14 & $-14 \%$ & -0.01 \\
\hline & 2011 & - & - & - & - & - & & & & & 2 & 0.08 & 0.05 & 0.04 & 0.12 & & & & \\
\hline & 2013 & - & - & - & - & - & & & & & 1 & 0.07 & NA & NA & NA & & & & \\
\hline \multirow[t]{3}{*}{$\overline{\mathrm{E} 2}$} & 2010 & - & - & - & - & - & - & - & - & - & 7 & 0.13 & 0.06 & 0.07 & 0.22 & $+38 \%$ & +0.05 & -- & -- \\
\hline & 2011 & - & - & - & - & - & & & & & 4 & 0.17 & 0.12 & 0.10 & 0.35 & & & & \\
\hline & 2013 & - & - & - & - & - & & & & & 0 & NA & NA & NA & NA & & & & \\
\hline \multirow[t]{3}{*}{ N4/N5 } & 2010 & - & - & - & - & - & - & - & - & - & 7 & 0.27 & 0.09 & 0.15 & 0.45 & $-20 \%$ & -0.05 & -- & -- \\
\hline & 2011 & - & - & - & - & - & & & & & 3 & 0.22 & 0.11 & 0.12 & 0.34 & & & & \\
\hline & 2013 & - & - & - & - & $\begin{array}{ll}- \\
-\end{array}$ & & & & & 0 & NA & NA & NA & NA & & & & \\
\hline \multirow[t]{3}{*}{ NCM } & 2010 & - & - & - & - & - & - & - & - & - & 6 & 0.74 & 0.49 & 0.26 & 1.52 & $+30 \%$ & +0.22 & $-73 \%$ & -0.71 \\
\hline & 2011 & - & - & - & - & - & & & & & 15 & 0.96 & 0.50 & 0.30 & 1.99 & & & & \\
\hline & 2013 & - & - & - & - & - & & & & & 15 & 0.26 & 0.14 & 0.10 & 0.71 & & & & \\
\hline \multirow[t]{3}{*}{$\overline{\mathrm{SF} 2}$} & 2010 & - & - & - & - & - & - & - & - & - & 3 & 0.10 & 0.03 & 0.07 & 0.13 & $-7 \%$ & \begin{tabular}{|c|}
-0.01 \\
\end{tabular} & $+47 \%$ & +0.04 \\
\hline & 2011 & - & - & - & - & - & & & & & 15 & 0.09 & 0.09 & 0.02 & 0.37 & & & & \\
\hline & 2013 & - & - & - & - & - & & & & & 8 & 0.13 & 0.08 & 0.06 & 0.31 & & & & \\
\hline
\end{tabular}


Table 2. Model selection results for egg total mercury concentrations (in micrograms per gram fresh wet weight) in American Avocets (Recurvirostra americana) nesting in South Bay Salt Pond Restoration Project area before (2010) and after (2011 and 2013) management activities associated with restoration of Pond A8/A7/A5 Complex, south San Francisco Bay, California, autumn 2010-spring 2011.

[Pond site was included as a random effect in all models. Model structure: The + denotes an additive effect and the $\times$ denotes an interaction. $\boldsymbol{k}$ : The number of parameters in the model, including the intercept and variance. AICc: Akaike's Information Criterion ( $\mathrm{AIC} c) . \triangle \mathrm{AIC} c$ : The difference in the value between $\mathrm{AIC} c$ of the current model and the value for the most parsimonious model. Akaike weight $\mathbf{t}\left(\boldsymbol{w}_{i}\right)$ :The likelihood of the model given the data, relative to other models in the candidate set (model weights sum to 1.0). Cumulative model weight: The cumulative weight of evidence for the top models (model weights sum to 1.0). Evidence ratio: The weight of evidence that the top model is better than the selected model, given the candidate model set.]

\begin{tabular}{|c|c|c|c|c|c|c|c|c|}
\hline Model structure & $\mathbf{N}$ & $\boldsymbol{k}$ & $-2 \log L$ & $\mathrm{AIC} c$ & $\triangle \mathrm{AIC} c$ & $\begin{array}{c}\text { Akaike } \\
\text { weight } \\
\left(w_{\mathrm{i}}\right)\end{array}$ & $\begin{array}{c}\text { Cumulative } \\
\text { model } \\
\text { weight }\end{array}$ & $\begin{array}{l}\text { Evidence } \\
\text { ratio }\end{array}$ \\
\hline Pond Type + Year + Date + Year $\times$ Date & 207 & 8 & 436.94 & 453.66 & 0.00 & 0.24 & 0.24 & 1.00 \\
\hline Year + Date + Year $\times$ Date & 207 & 7 & 440.13 & 454.70 & 1.03 & 0.14 & 0.38 & 1.68 \\
\hline Pond Type + Year + Date + Date $^{2}+$ Year $\times$ Date & 207 & 9 & 436.00 & 454.92 & 1.25 & 0.13 & 0.51 & 1.87 \\
\hline Pond Type + Year + Date + Pond Type $\times$ Date + Year $\times$ Date & 207 & 9 & 436.37 & 455.28 & 1.62 & 0.11 & 0.61 & 2.25 \\
\hline $\begin{array}{l}\text { Pond Type }+ \text { Year }+ \text { Date }+ \text { Date }^{2}+\text { Pond Type } \times \text { Date }+ \\
\text { Year } \times \text { Date }\end{array}$ & 207 & 10 & 434.77 & 455.89 & 2.23 & 0.08 & 0.69 & 3.05 \\
\hline Year + Date + Date $^{2}+$ Year $\times$ Date & 207 & 8 & 439.25 & 455.97 & 2.31 & 0.08 & 0.77 & 3.17 \\
\hline Pond Type + Year + Date + Pond Type $\times$ Year + Year $\times$ Date & 207 & 10 & 436.08 & 457.20 & 3.54 & 0.04 & 0.81 & 5.87 \\
\hline Pond Type + Year & 207 & 5 & 447.69 & 457.99 & 4.33 & 0.03 & 0.83 & 8.71 \\
\hline $\begin{array}{l}\text { Pond Type }+ \text { Year }+ \text { Date }+ \text { Pond Type } \times \text { Year }+ \text { Pond } \\
\text { Type } \times \text { Date }+ \text { Year } \times \text { Date }\end{array}$ & 207 & 11 & 434.85 & 458.20 & 4.54 & 0.02 & 0.86 & 9.67 \\
\hline Pond Type + Year + Date & 207 & 6 & 445.93 & 458.35 & 4.69 & 0.02 & 0.88 & 10.43 \\
\hline $\begin{array}{l}\text { Pond Type }+ \text { Year }+ \text { Date }+ \text { Date }^{2}+\text { Pond Type } \times \text { Year }+ \\
\text { Year } \times \text { Date }\end{array}$ & 207 & 11 & 435.34 & 458.70 & 5.03 & 0.02 & 0.90 & 12.39 \\
\hline $\begin{array}{l}\text { Pond Type }+ \text { Year }+ \text { Date }+ \text { Date }^{2}+\text { Pond Type } \times \text { Year }+ \text { Pond } \\
\text { Type } \times \text { Date }+ \text { Year } \times \text { Date }\end{array}$ & 207 & 12 & 433.30 & 458.91 & 5.25 & 0.02 & 0.92 & 13.80 \\
\hline Year & 207 & 4 & 451.09 & 459.29 & 5.63 & 0.01 & 0.93 & 16.66 \\
\hline Year + Date & 207 & 5 & 449.06 & 459.36 & 5.69 & 0.01 & 0.95 & 17.22 \\
\hline Pond Type + Year + Date + Date $^{2}$ & 207 & 7 & 444.96 & 459.52 & 5.85 & 0.01 & 0.96 & 18.68 \\
\hline Pond Type + Year + Date + Pond Type $\times$ Date & 207 & 7 & 445.01 & 459.58 & 5.91 & 0.01 & 0.97 & 19.23 \\
\hline Pond Type + Year + Date + Date $^{2}+$ Pond Type $\times$ Date & 207 & 8 & 443.20 & 459.92 & 6.26 & 0.01 & 0.98 & 22.87 \\
\hline Year + Date + Date $^{2}$ & 207 & 6 & 448.13 & 460.55 & 6.89 & 0.01 & 0.99 & 31.30 \\
\hline Pond Type + Year + Pond Type $\times$ Year & 207 & 7 & 447.57 & 462.14 & 8.47 & 0.00 & 0.99 & 69.13 \\
\hline Pond Type + Year + Date + Pond Type $\times$ Year & 207 & 8 & 445.80 & 462.53 & 8.87 & 0.00 & 1.00 & 84.23 \\
\hline $\begin{array}{l}\text { Pond Type }+ \text { Year }+ \text { Date }+ \text { Pond Type } \times \text { Year }+ \text { Pond } \\
\text { Type } \times \text { Date }\end{array}$ & 207 & 9 & 444.72 & 463.64 & 9.97 & 0.00 & 1.00 & 146.53 \\
\hline Pond Type + Year + Date + Date $^{2}+$ Pond Type $\times$ Year & 207 & 9 & 444.79 & 463.70 & 10.04 & 0.00 & 1.00 & 151.18 \\
\hline $\begin{array}{l}\text { Pond Type }+ \text { Year }+ \text { Date }+ \text { Date }^{2}+\text { Pond Type } \times \text { Year }+ \text { Pond } \\
\text { Type } \times \text { Date }\end{array}$ & 207 & 10 & 442.94 & 464.06 & 10.40 & 0.00 & 1.00 & 181.01 \\
\hline Pond Type + Date + Date $^{2}+$ Pond Type $\times$ Date & 207 & 6 & 458.56 & 470.98 & 17.31 & 0.00 & 1.00 & 5744.27 \\
\hline Pond Type & 207 & 3 & 465.45 & 471.57 & 17.91 & 0.00 & 1.00 & 7734.08 \\
\hline Pond Type + Date + Date $^{2}$ & 207 & 5 & 462.18 & 472.48 & 18.81 & 0.00 & 1.00 & 12177.19 \\
\hline Pond Type + Date & 207 & 4 & 464.65 & 472.85 & 19.19 & 0.00 & 1.00 & 14672.54 \\
\hline Pond Type + Date + Pond Type $\times$ Date & 207 & 5 & 462.79 & 473.08 & 19.42 & 0.00 & 1.00 & 16486.31 \\
\hline Null (Intercept Only) & 207 & 2 & 469.19 & 473.24 & 19.58 & 0.00 & 1.00 & 17858.89 \\
\hline Date + Date $^{2}$ & 207 & 4 & 465.72 & 473.92 & 20.25 & 0.00 & 1.00 & 25005.32 \\
\hline Date & 207 & 3 & 468.23 & 474.34 & 20.68 & 0.00 & 1.00 & 30952.11 \\
\hline
\end{tabular}




\section{American Avocet}

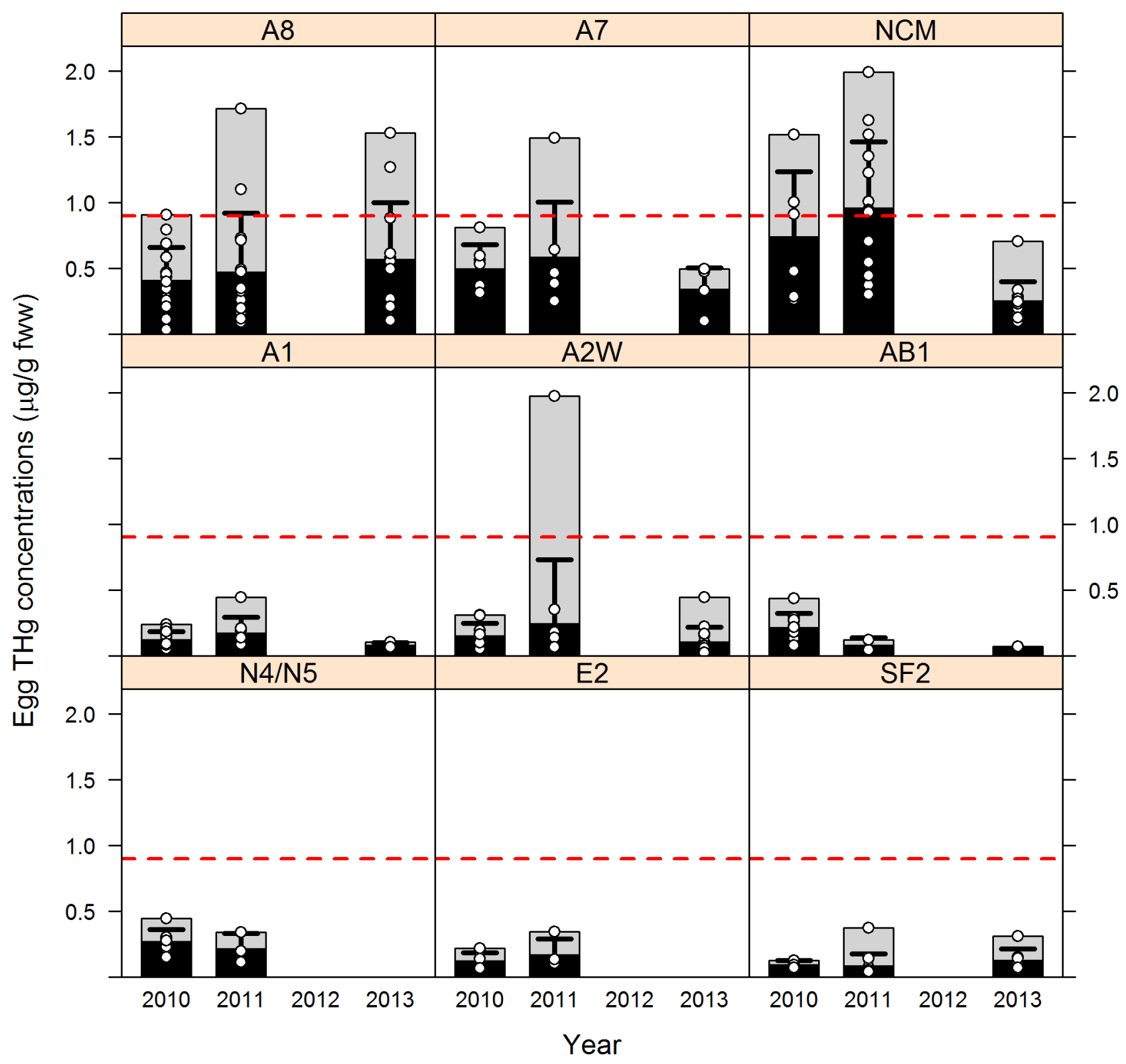

Figure 2. Pond site and year differences in egg total mercury ( $\mathrm{THg}$ ) concentrations (in micrograms per gram fresh wet weight, $\mu \mathrm{g} / \mathrm{g}$ fww) for American Avocets (Recurvirostra americana) nesting in South Bay Salt Pond Restoration Project area, south San Francisco Bay, California. The horizontal black bar represents the arithmetic mean of egg mercury concentrations. The error bar represents the standard deviation of the data. The gray box indicates the maximum egg mercury concentration observed. The white circles show the actual mercury concentration for each individual egg. The red dashed line indicates the toxicity threshold of $0.90 \mu \mathrm{g} / \mathrm{g}$ fww, where bird reproduction may be impaired (Ackerman and EaglesSmith, 2008, unpublished). 

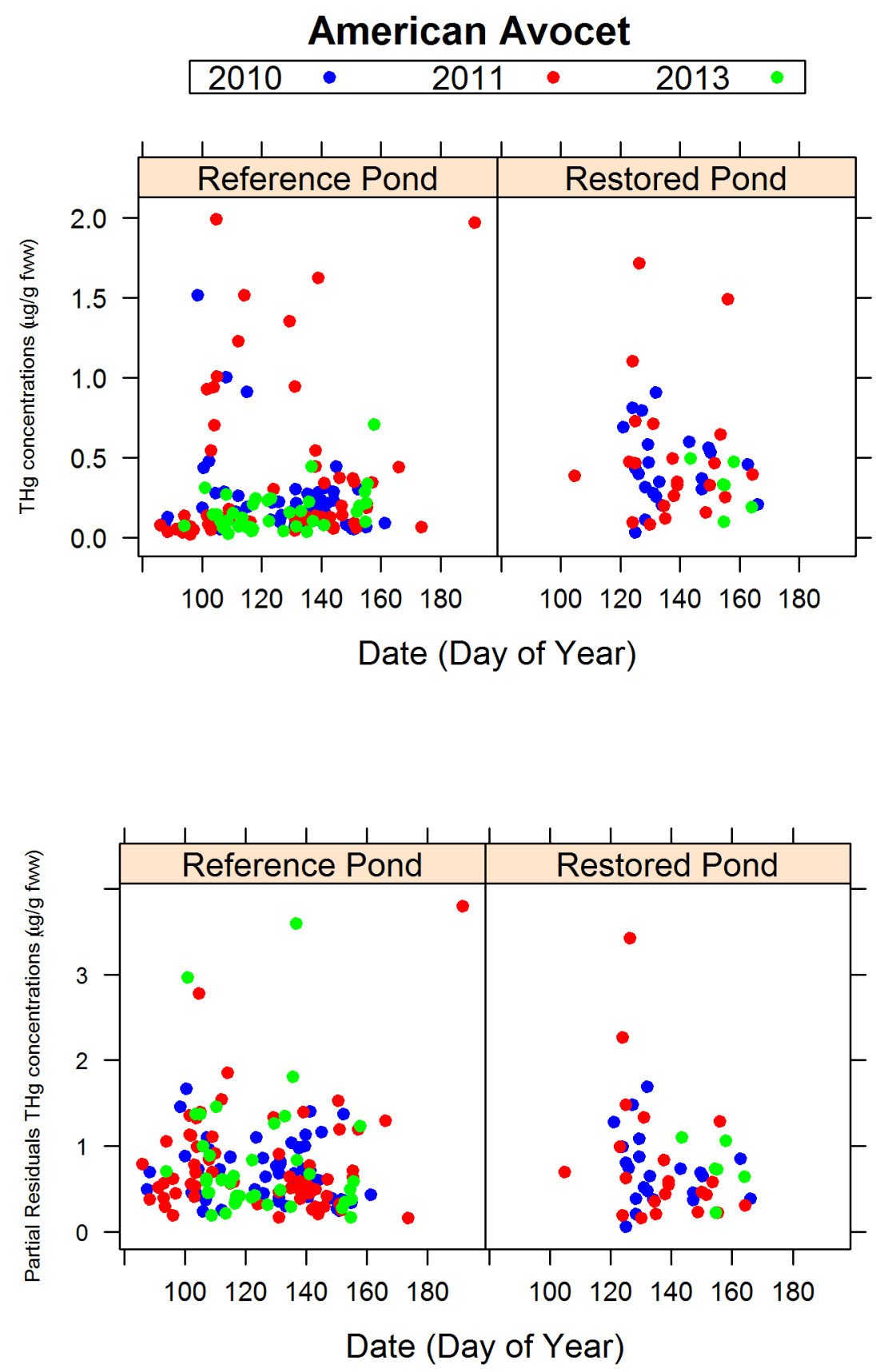

Figure 3. Total mercury (THg) concentrations (in micrograms per gram fresh wet weight, $\mu \mathrm{g} / \mathrm{g} \mathrm{fww}$ ) in American Avocet (Recurvirostra americana) eggs by date in South Bay Salt Pond Restoration Project area before (2010, blue dots) and after (2011, red dots; 2013, green dots) management activities associated with restoration of Pond A8/A7/A5 Complex, south San Francisco Bay, California, autumn 2010-spring 2011. Pond A8 Notch was opened on June 1, 2011, and June 6, 2013, corresponding to a potential exposure to eggs by June 8, 2011 (day of year=159) and June 13, 2013 (day of year=164). The top panels indicate the raw data, and the bottom panels show the partial residuals from the model. 


\section{American Avocet}

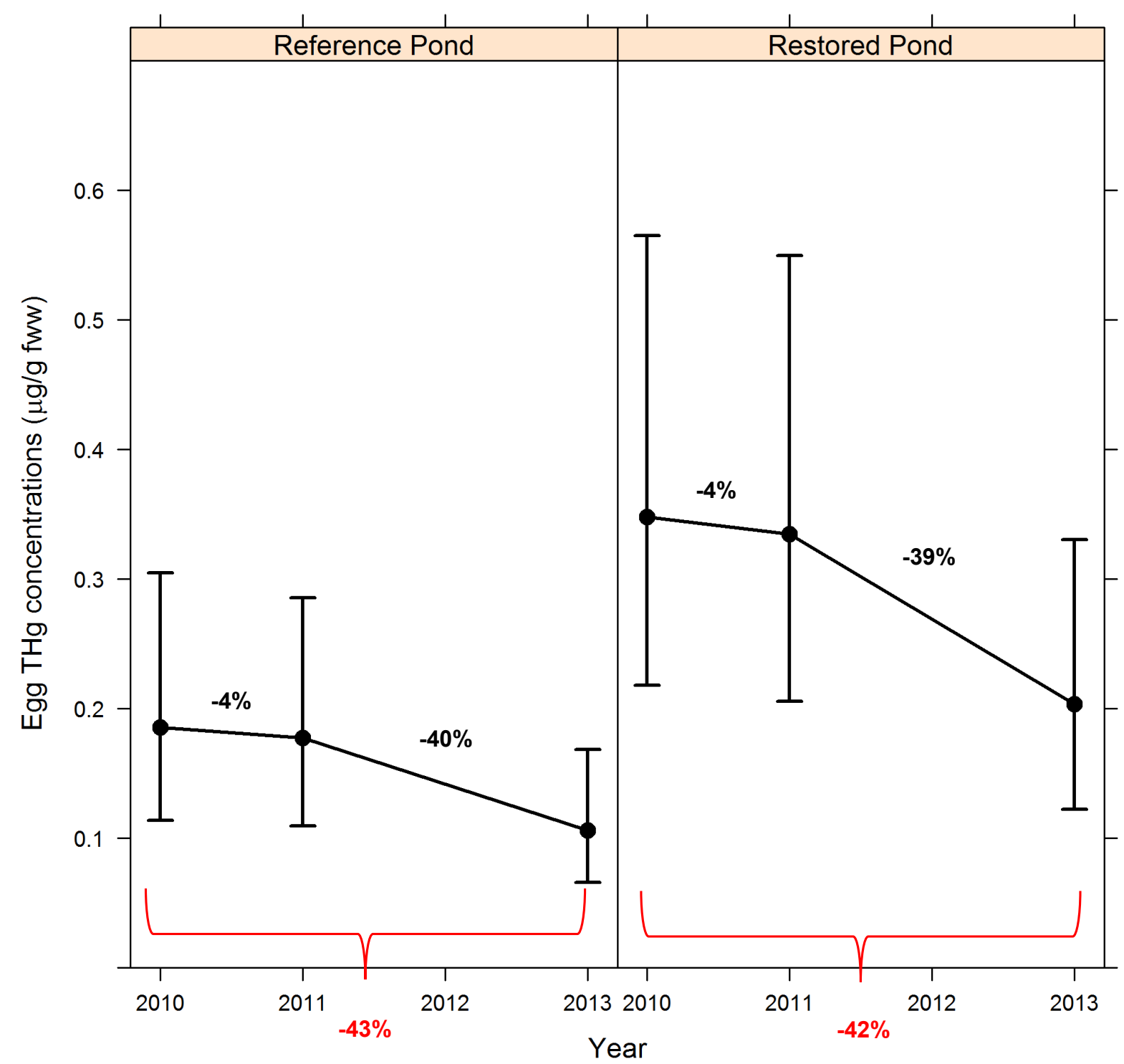

Figure 4. Model-averaged mean and 95-percent credible intervals for total mercury $(\mathrm{THg})$ concentrations (in micrograms per gram fresh wet weight, $\mu \mathrm{g} / \mathrm{g} \mathrm{fww}$ ) in American Avocet (Recurvirostra americana) eggs in South Bay Salt Pond Restoration Project area before (2010) and after (2011 and 2013) management activities associated with restoration of Pond A8/A7/A5 Complex, south San Francisco Bay ,California, autumn 2010-spring 2011. 


\section{Forster's Terns (Sterna forsteri)}

Across all ponds and years, Tern egg THg concentrations ranged from 0.44 to $7.33 \mu \mathrm{g} / \mathrm{g}$ fww, with an arithmetic mean of $1.63 \mu \mathrm{g} / \mathrm{g}$ fww ( $N=180$ eggs; table 1). Overall, 60 percent of randomly sampled Tern eggs in 2013 exceeded the toxicity threshold developed for Forster's Terns in San Francisco Bay (0.90 $\mu \mathrm{g} / \mathrm{g}$ fww; Ackerman and Eagles-Smith, 2008, unpublished).

The most parsimonious model describing Tern egg THg concentrations included pond type, year, date, and the interactions pond type $\times$ year and year $\times$ date, and had an Akaike weight of 0.27 (table 3 ). Furthermore, all models containing year, pond type, and pond type $\times$ year interaction had a cumulative Akaike weight of 0.99. Two other models containing these three variables plus either date or date ${ }^{2}$, had a change in AIC $c$ value of less than or equal to 2.0 from that of the most parsimonious model $(\triangle \mathrm{AIC} c \leq 2.0$; table 3$)$. We estimated the relative importance of individual variables and determined that the data strongly supported effects of year (relative variable importance $=1.00)$, pond type $(0.99)$, date $(0.94)$, and the pond type $\times$ year interaction (0.99). In contrast, year $\times$ date interaction $(0.48)$, date ${ }^{2}(0.29)$, and pond type $\times$ date interaction (0.23) had little support. Using evidence ratios, we estimated that the best model that included the pond type $\times$ year interaction was 3,295 times more likely than the same model without this interaction. Similarly, the best model was 9,930 times more likely than the same model but without the pond type variable, and $2.29 \times 10^{17}$ times more likely than the same model but without the year variable. There was some support for an increase in Tern egg THg concentrations with date, especially in 2011 after the Pond A8 Notch was opened. However, the influence of date on egg THg concentrations was relatively small relative to the effects of other variables. The arithmetic mean of egg THg concentrations for Terns by year for each pond is shown in figure 5 . The raw and model-predicted (partial residual) egg $\mathrm{THg}$ concentrations for each Tern egg by date for Reference and Restored Ponds is shown in figure 6.

The overriding importance of year, pond type, and pond type $\times$ year interaction indicated that changes in Tern egg THg concentrations between years were not consistent among pond types (Restored Ponds compared to Reference Ponds). Specifically, model-predicted (at mean nest initiation day of year $=156$ ) mean $\mathrm{THg}$ concentrations in Tern eggs increased by 69 percent between 2010 and 2011 at Restored Ponds (2010, $1.60 \mu \mathrm{g} / \mathrm{g}$ fww; 2011, $2.71 \mu \mathrm{g} / \mathrm{g} \mathrm{fww})$, but mean egg $\mathrm{THg}$ concentrations decreased slightly by 10 percent between years at Reference Ponds (2010, $1.50 \mu \mathrm{g} / \mathrm{g}$ fww; 2011, $1.35 \mu \mathrm{g} / \mathrm{g}$ fww) (fig. 7). Thereafter, mean Tern egg THg concentrations decreased by 59 percent between 2011 and 2013 at Restored Ponds $(2011,2.71$ $\mu \mathrm{g} / \mathrm{g}$ fww; 2013, $1.10 \mu \mathrm{g} / \mathrm{g}$ fww), and decreased by 23 percent between years at Reference Ponds (2011, $1.35 \mu \mathrm{g} / \mathrm{g}$ fww; 2013, $1.04 \mu \mathrm{g} / \mathrm{g}$ fww) (fig. 7). The end result of this 3-year comparison was that model-predicted mean egg THg concentration in Terns decreased between 2010 and 2013 by 31 percent at both Restored and Reference Ponds (fig. 7). Thus, Tern egg THg concentrations in 2013 returned to equivalent baseline concentrations measured in 2010 before any of the restoration actions were conducted. Importantly, Tern egg THg concentrations in the Restored Ponds still were 6 percent higher than concentrations in the Reference Ponds in 2013 (Restored Ponds, $1.10 \mu \mathrm{g} / \mathrm{g}$ fww; Reference Ponds, $1.04 \mu \mathrm{g} / \mathrm{g}$ fww), similar to the 2010 baseline $\mathrm{THg}$ concentration trajectory in Tern eggs, where Restored Ponds had concentrations 7 percent higher than Reference Ponds (Restored Ponds, $1.60 \mu \mathrm{g} / \mathrm{g}$ fww; Reference Ponds, $1.50 \mu \mathrm{g} / \mathrm{g}$ fww) (fig. 7). Pond-specific percent changes in the arithmetic means of Tern egg THg concentration, based on raw data, are shown in table 1. 
Table 3. Model selection results for egg total mercury concentrations micrograms per gram fresh wet weight) in Forster's Terns (Sterna forsteri) nesting in South Bay Salt Pond Restoration Project area before (2010) and after (2011 and 2013) management activities associated with restoration of the Pond A8/A7/A5 Complex, south San Francisco Bay, California, autumn 2010-spring 2011.

[Pond site was included as a random effect in all models. Model structure: The + denotes an additive effect and the $\times$ denotes an interaction. $\boldsymbol{k}$ : The number of parameters in the model, including the intercept and variance. AIC $\boldsymbol{c}$ : Akaike's Information Criterion (AICc). $\triangle \mathrm{AIC} c$ : The difference in the value between AIC $c$ of the current model and the value for the most parsimonious model. Akaike weight $\mathbf{t}\left(\boldsymbol{w}_{i}\right)$ :The likelihood of the model given the data, relative to other models in the candidate set (model weights sum to 1.0). Cumulative model weight: The cumulative weight of evidence for the top models (model weights sum to 1.0). Evidence ratio: The weight of evidence that the top model is better than the selected model, given the candidate model set]

\begin{tabular}{|c|c|c|c|c|c|c|c|c|}
\hline Model structure & $\mathbf{N}$ & $k$ & $-2 \log L$ & $\mathrm{AIC} c$ & $\triangle \mathrm{AIC} c$ & $\begin{array}{c}\text { Akaike } \\
\text { weight }\left(w_{\mathrm{i}}\right)\end{array}$ & $\begin{array}{c}\text { Cumulative } \\
\text { model } \\
\text { weight }\end{array}$ & $\begin{array}{l}\text { Evidence } \\
\text { ratio }\end{array}$ \\
\hline $\begin{array}{l}\text { Pond Type }+ \text { Year }+ \text { Date }+ \text { Pond } \\
\text { Type } \times \text { Year }+ \text { Year } \times \text { Date }\end{array}$ & 178 & 10 & 131.20 & 152.51 & 0.00 & 0.27 & 0.27 & 1.00 \\
\hline $\begin{array}{l}\text { Pond Type }+ \text { Year }+ \text { Date }+ \text { Pond } \\
\text { Type } \times \text { Year }\end{array}$ & 178 & 8 & 136.11 & 152.96 & 0.44 & 0.22 & 0.49 & 1.25 \\
\hline $\begin{array}{l}\text { Pond Type }+ \text { Year }+ \text { Date }+ \text { Date }^{2}+ \\
\text { Pond Type } \times \text { Year }\end{array}$ & 178 & 9 & 134.99 & 154.06 & 1.55 & 0.12 & 0.61 & 2.17 \\
\hline $\begin{array}{l}\text { Pond Type }+ \text { Year }+ \text { Date }+ \text { Date }^{2}+ \\
\text { Pond Type } \times \text { Year }+ \text { Year } \times \text { Date }\end{array}$ & 178 & 11 & 131.01 & 154.60 & 2.09 & 0.10 & 0.71 & 2.84 \\
\hline $\begin{array}{l}\text { Pond Type }+ \text { Year }+ \text { Date }+ \text { Pond } \\
\text { Type } \times \text { Year }+ \text { Pond Type } \times \text { Date }+ \\
\text { Year } \times \text { Date }\end{array}$ & 178 & 11 & 131.20 & 154.79 & 2.27 & 0.09 & 0.79 & 3.12 \\
\hline $\begin{array}{l}\text { Pond Type }+ \text { Year }+ \text { Date }+ \text { Pond } \\
\text { Type } \times \text { Year }+ \text { Pond Type } \times \text { Date }\end{array}$ & 178 & 9 & 136.09 & 155.16 & 2.65 & 0.07 & 0.87 & 3.76 \\
\hline Pond Type + Year + Pond Type $\times$ Year & 178 & 7 & 140.78 & 155.44 & 2.92 & 0.06 & 0.93 & 4.31 \\
\hline $\begin{array}{l}\text { Pond Type }+ \text { Year }+ \text { Date }+ \text { Date }{ }^{2}+ \\
\text { Pond Type } \times \text { Year }+ \text { Pond Type } \times \text { Date }\end{array}$ & 178 & 10 & 134.99 & 156.31 & 3.80 & 0.04 & 0.97 & 6.68 \\
\hline $\begin{array}{l}\text { Pond Type }+ \text { Year }+ \text { Date }+ \text { Date }^{2}+ \\
\text { Pond Type } \times \text { Year }+ \text { Pond Type } \times \text { Date }+ \\
\text { Year } \times \text { Date }\end{array}$ & 178 & 12 & 131.01 & 156.90 & 4.39 & 0.03 & 1.00 & 8.97 \\
\hline $\begin{array}{l}\text { Pond Type }+ \text { Year }+ \text { Date }+ \text { Pond } \\
\text { Type } \times \text { Date }+ \text { Year } \times \text { Date }\end{array}$ & 178 & 9 & 146.58 & 165.65 & 13.14 & 0.00 & 1.00 & 712.44 \\
\hline $\begin{array}{l}\text { Pond Type }+ \text { Year }+ \text { Date }+ \text { Date }^{2}+ \\
\text { Pond Type } \times \text { Date }+ \text { Year } \times \text { Date }\end{array}$ & 178 & 10 & 146.01 & 167.32 & 14.81 & 0.00 & 1.00 & $1,644.83$ \\
\hline $\begin{array}{l}\text { Pond Type }+ \text { Year }+ \text { Date }+ \text { Pond } \\
\text { Type } \times \text { Date }\end{array}$ & 178 & 7 & 153.92 & 168.58 & 16.07 & 0.00 & 1.00 & $3,087.35$ \\
\hline Pond Type + Year + Date + Year $\times$ Date & 178 & 8 & 151.86 & 168.71 & 16.20 & 0.00 & 1.00 & $3,295.00$ \\
\hline $\begin{array}{l}\text { Pond Type }+ \text { Year }+ \text { Date }+ \text { Date }^{2}+ \\
\text { Pond Type } \times \text { Date }\end{array}$ & 178 & 8 & 151.89 & 168.74 & 16.23 & 0.00 & 1.00 & $3,339.54$ \\
\hline $\begin{array}{l}\text { Pond Type }+ \text { Year }+ \text { Date }+ \text { Date }^{2}+ \\
\text { Year } \times \text { Date }\end{array}$ & 178 & 9 & 151.24 & 170.31 & 17.80 & 0.00 & 1.00 & $7,318.32$ \\
\hline Year + Date + Year $\times$ Date & 178 & 7 & 156.05 & 170.71 & 18.19 & 0.00 & 1.00 & $8,930.19$ \\
\hline Year + Date + Date $^{2}+$ Year $\times$ Date & 178 & 8 & 155.67 & 172.53 & 20.01 & 0.00 & 1.00 & $22,165.28$ \\
\hline Pond Type + Year & 178 & 5 & 162.52 & 172.87 & 20.36 & 0.00 & 1.00 & $26,362.35$ \\
\hline Pond Type + Year + Date + Date $^{2}$ & 178 & 7 & 159.42 & 174.08 & 21.57 & 0.00 & 1.00 & $48,175.65$ \\
\hline Pond Type + Year + Date & 178 & 6 & 162.51 & 175.00 & 22.49 & 0.00 & 1.00 & $76,547.58$ \\
\hline Year + Date + Date $^{2}$ & 178 & 6 & 164.75 & 177.24 & 24.73 & 0.00 & 1.00 & $234,486.76$ \\
\hline Year & 178 & 4 & 169.37 & 177.61 & 25.09 & 0.00 & 1.00 & $281,087.29$ \\
\hline Year + Date & 178 & 5 & 169.37 & 179.71 & 27.20 & 0.00 & 1.00 & $806,721.40$ \\
\hline $\begin{array}{l}\text { Pond Type }+ \text { Date }+ \text { Date }^{2}+\text { Pond } \\
\text { Type } \times \text { Date }\end{array}$ & 178 & 6 & 215.91 & 228.40 & 75.89 & 0.00 & 1.00 & $3.01 \times 10^{16}$ \\
\hline Pond Type + Date + Date $^{2}$ & 178 & 5 & 219.25 & 229.60 & 77.09 & 0.00 & 1.00 & $5.49 \times 10^{16}$ \\
\hline Pond Type + Date + Pond Type $\times$ Date & 178 & 5 & 219.75 & 230.10 & 77.59 & 0.00 & 1.00 & $7.05 \times 10^{16}$ \\
\hline Date + Date $^{2}$ & 178 & 4 & 222.82 & 231.05 & 78.54 & 0.00 & 1.00 & $1.13 \times 10^{17}$ \\
\hline Pond Type + Date & 178 & 4 & 224.23 & 232.46 & 79.95 & 0.00 & 1.00 & $2.29 \times 10^{17}$ \\
\hline Date & 178 & 3 & 230.01 & 236.15 & 83.64 & 0.00 & 1.00 & $1.45 \times 10^{18}$ \\
\hline Pond Type & 178 & 3 & 247.28 & 253.41 & 100.90 & 0.00 & 1.00 & $8.14 \times 10^{21}$ \\
\hline Null (Intercept Only) & 178 & 2 & 253.90 & 257.97 & 105.46 & 0.00 & 1.00 & $7.94 \times 10^{22}$ \\
\hline
\end{tabular}




\section{Forster's Tern}

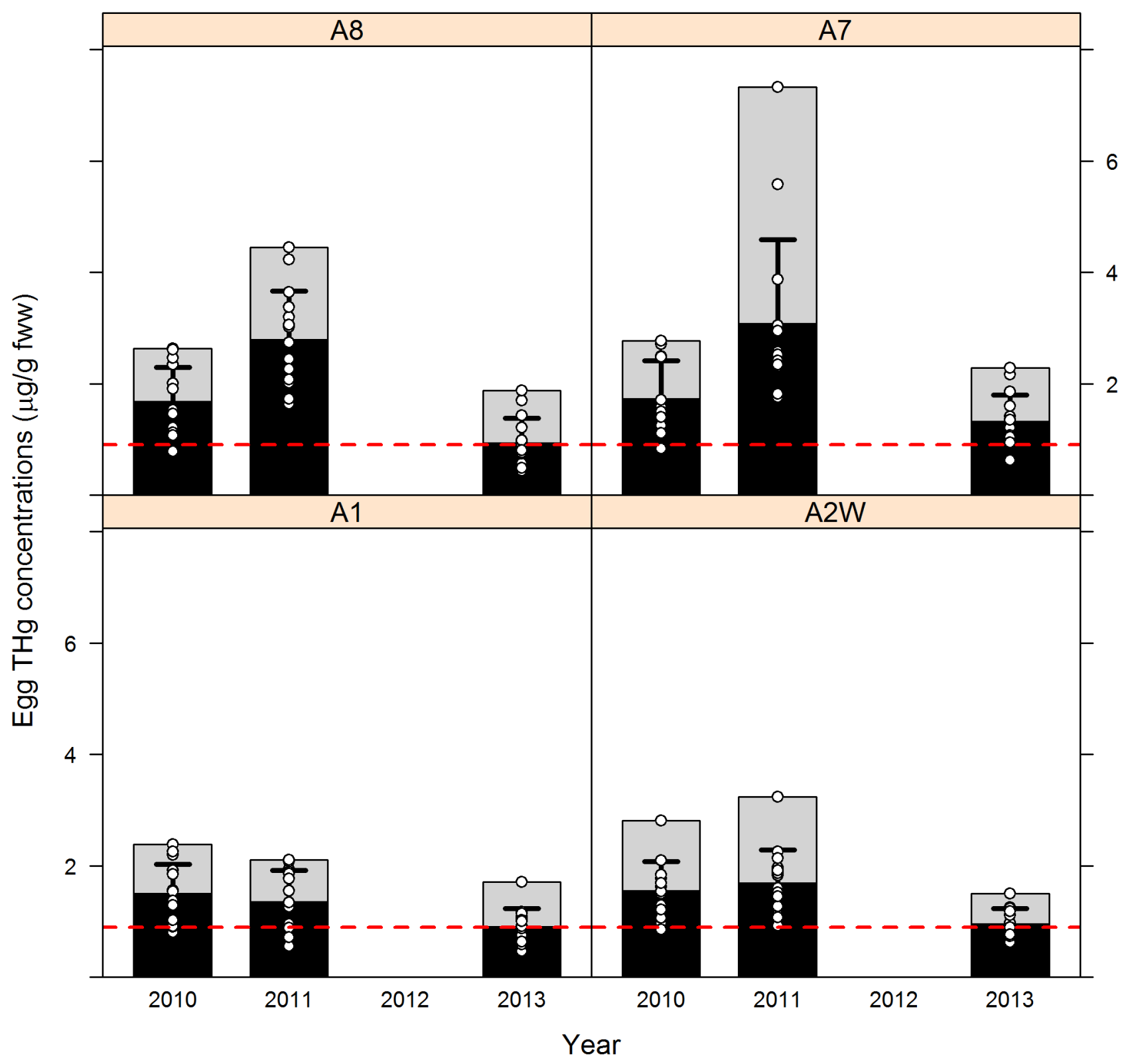

Figure 5. Pond site and year differences in egg total mercury ( $\mathrm{THg}$ ) concentrations (in micrograms per gram fresh wet weight, $\mu \mathrm{g} / \mathrm{g} \mathrm{fww}$ ) for Forster's Terns (Sterna forsteri) nesting in South Bay Salt Pond Restoration Project area, south San Francisco Bay, California. The horizontal black bar represents the arithmetic mean egg mercury concentrations. The error bar represents the standard deviation of the data. The gray box indicates the maximum egg mercury concentration observed. The white circles show the actual mercury concentration for each individual egg. The red dashed line indicates the toxicity threshold of $0.90 \mu \mathrm{g} / \mathrm{g}$ fww where bird reproduction may be impaired (Ackerman and Eagles-Smith, 2008, unpublished). 

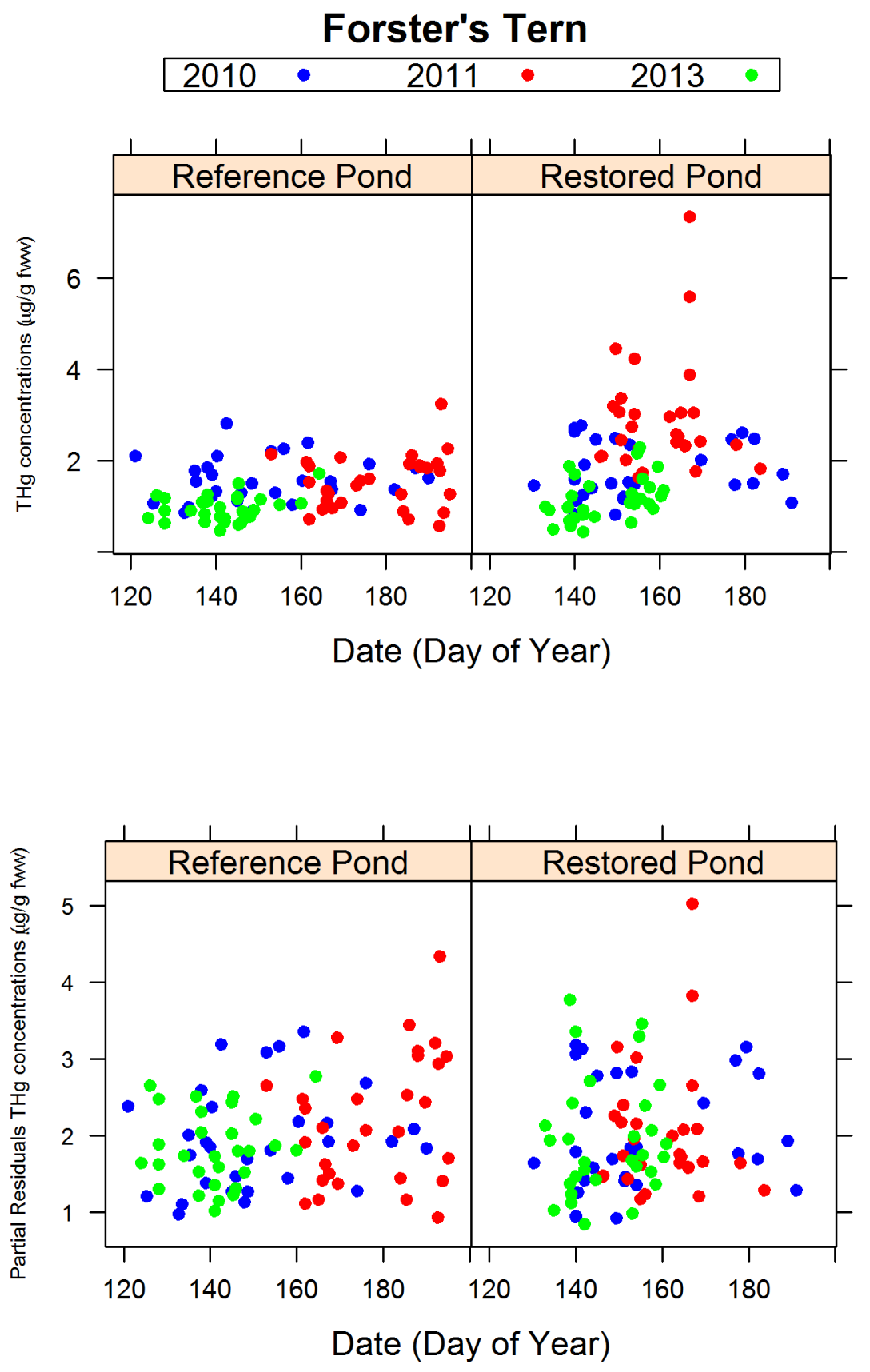

Figure 6. Total mercury (THg) concentrations (in micrograms per gram fresh wet weight, $\mu \mathrm{g} / \mathrm{g} \mathrm{fww}$ ) in Forster's Tern (Sterna forsteri) eggs by date in South Bay Salt Pond Restoration Project area before (2010, blue dots) and after (2011, red dots; 2013, green dots) management activities associated with restoration of Pond A8/A7/A5 Complex, south San Francisco Bay, California, autumn 2010-spring 2011. Pond A8 Notch was opened on June 1, 2011, and June 6, 2013, corresponding to a potential exposure to eggs by June 8, 2011 (day of year=159) and June 13, 2013 (day of year=164). The top panels indicate raw data and the bottom panels display the partial residuals from the model. 


\section{Forster's Tern}

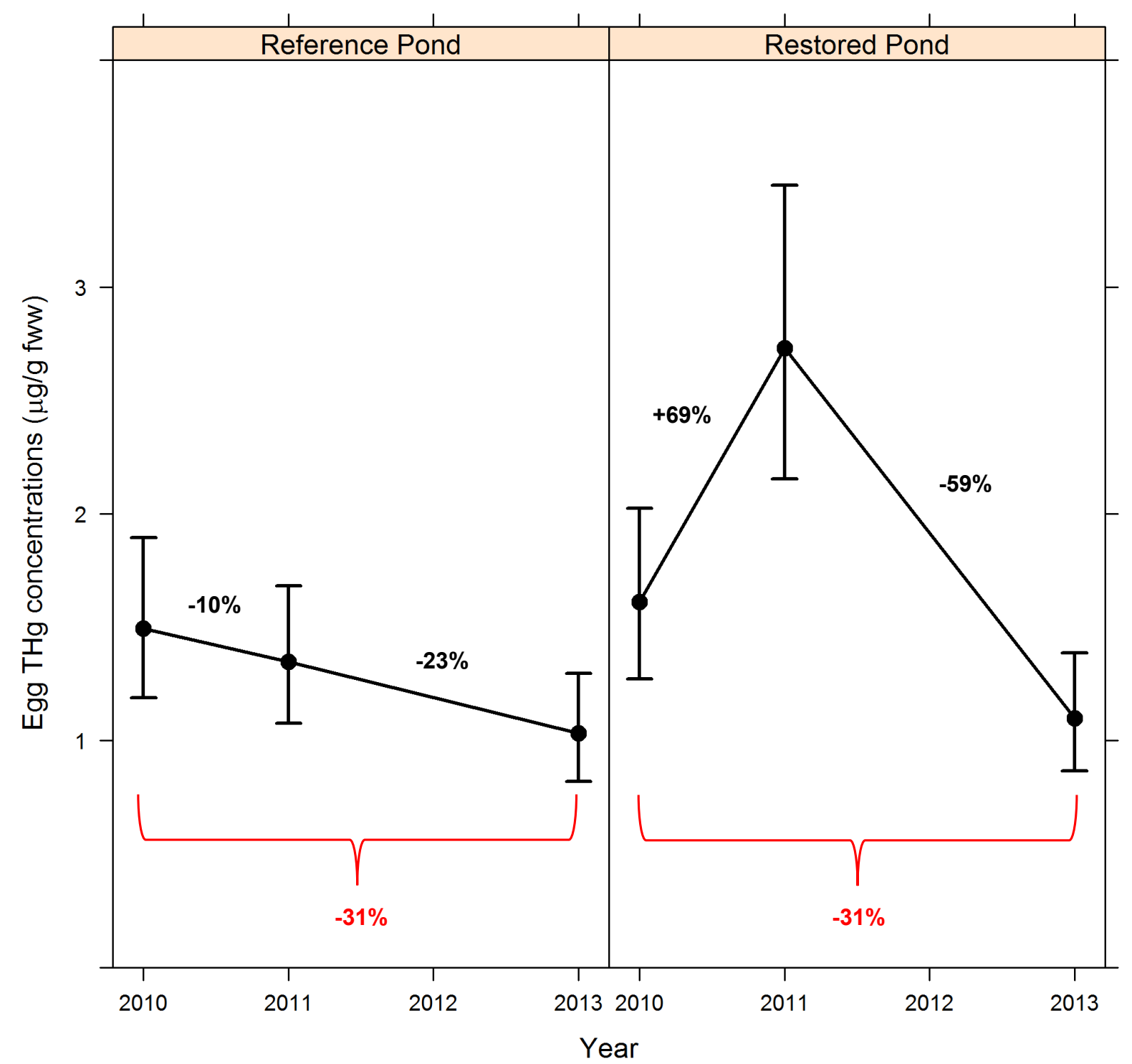

Figure 7. Model-averaged mean and 95-percent credible intervals for total mercury (THg) concentrations (in micrograms per gram fresh wet weight, $\mu \mathrm{g} / \mathrm{g}$ fww) in Forster's Tern (Sterna forsteri) eggs in South Bay Salt Pond Restoration Project area before (2010) and after (2011 and 2013) management activities associated with restoration of Pond A8/A7/A5 Complex, south San Francisco Bay ,California, autumn 2010-spring 2011. 


\section{Management Implications}

These results indicate that, although there was a significant short-term influence of the restoration actions on increased $\mathrm{Hg}$ bioaccumulation in Tern eggs the following year, this effect appeared to be short-lived. However, the restoration project apparently has not changed baseline mercury $(\mathrm{Hg})$ conditions in eggs at the Restored Ponds-Ponds A7 and A8 - are still Hg "hotspots" for bird eggs (especially in Tern eggs compared to other ponds in 2013) 2 years after the restoration action. For example, the arithmetic mean of Tern egg total mercury ( $\mathrm{THg}$ ) concentrations in Restored Pond A7 was $1.33 \mu \mathrm{g} / \mathrm{g}$ fww in 2013, which is 38 percent higher than the highest reference site at Pond A2W $(0.97 \mu \mathrm{g} / \mathrm{g}$ fww) (table 1). Moreover, most Tern egg Hg concentrations in the Restored Ponds in 2013 (70 percent) still remain higher than concentrations associated with reproductive impairment. Egg THg concentrations at these concentrations previously have been shown to reduce hatching success and nest survival, to increase the likelihood of embryos being malpositioned within eggs, to suppress baseline corticosterone concentrations in juvenile birds, to increase adult demethylation rates in bird livers, and to reduce adult body condition (Ackerman and Eagles-Smith, 2008, unpublished, Ackerman and others, 2008a,b,c, Eagles-Smith and others, 2009a,b, Herring and others, 2010, Ackerman and others, 2009, Ackerman and others, 2011, Ackerman and others, 2012a, Herring and others, 2012).

Despite the significant increase and correspondingly large decrease in $\mathrm{THg}$ concentrations in Tern eggs at the Restored Ponds, both Tern and Avocet egg THg concentrations in the Restored Ponds still are similar to concentrations that would have been expected without the occurrence of the restoration actions. Although ambient egg $\mathrm{THg}$ concentrations in the south San Francisco Bay have decreased since 2010, the restoration actions apparently did not change the baseline $\mathrm{Hg}$ concentration trajectory in eggs within the Restored Ponds. In particular, Ponds A7 and A8 still are $\mathrm{Hg}$ "hotspots" for both Terns and Avocets 2 years after the restoration actions. It will be important to document whether egg $\mathrm{THg}$ concentrations continue to decrease in the future as the Restored Ponds continue to develop, the Pond A8 Notch is opened for a longer portion of the year, the gates are opened earlier (March 6 in 2014), and more gates are opened (currently [2014] only three of eight gates are being opened). With further decreases relative to the Reference Ponds, the Restored Ponds possibly could achieve lower egg THg concentrations than would have been expected without any restoration actions, but the South Bay Salt Pond Restoration Project has not achieved this goal as of 2013. These data suggest that continued monitoring of waterbird egg $\mathrm{THg}$ concentrations in the restoration project area, relative to reference sites, is warranted over a period of multiple years.

\section{Acknowledgments}

This study was funded and supported by the U.S. Environmental Protection Agency, the State of California Coastal Conservancy, and the South Bay Salt Pond Restoration Project. Logistical support was kindly provided by Cheryl Strong, Eric Mruz, Laura Valoppi, John Bourgeois, and John Krause, and the staffs of the Don Edwards San Francisco Bay National Wildlife Refuge and Eden Landing Ecological Reserve. We thank the following U.S. Geological Survey Western Ecological Research Center field and laboratory technicians who helped with this research: Ashley Casey, Rosielyn DeGuzman, Michelle Boyles, Laura Young, and Erik Nass. 


\section{Unpublished Data Referenced}

Ackerman, J.T., and Eagles-Smith, C.A., 2008, A dual life-stage approach to monitoring the effects of mercury concentrations on the reproductive success of Forster's Terns in San Francisco Bay-Annual report: U.S. Geological Survey, Western Ecological Research Center, Davis, California, $44 \mathrm{p}$.

Ackerman, J. T., Eagles-Smith, C.A., Heinz, G.H., Wainwright-De La Cruz, S.E., Takekawa, J.Y., Adelsbach, T.L., Miles, A.K.,Hoffman, D.J., Schwarzbach, S.E., Suchanek, T.H., and Maurer, T.C., 2007b, Mercury in birds of the San Francisco Bay-Delta-Trophic pathways, bioaccumulation and Eco toxicological risk to avian reproduction: 2006 Annual Report to CALFED, U.S. Geological Survey, Western Ecological Research Center, and U. S. Fish and Wildlife Service, Environmental Contaminants Division, $41 \mathrm{p}$.

Ackerman, J.T., Herzog, M.P., and Hartman, C.A., 2012b, The South Bay Mercury ProjectUsing biosentinels to monitor effects of wetland restoration for the South Bay Salt Pond Restoration Project (waterbird mercury component): U.S. Geological Survey, Western Ecological Research Center, Davis, California, 79 p.

Ackerman, J.T., Marvin-DiPasquale, M., Slotton, D., Eagles-Smith, C.A., Herzog, M.P., Hartman, C.A., Agee, J.L., and Ayers, S., 2013a, The South Bay Mercury Project-Using biosentinels to monitor effects of wetland restoration for the South Bay Salt Pond Restoration Project: U.S. Geological Survey, Western Ecological Research Center, Davis, California, $227 \mathrm{p}$.

\section{References Cited}

Ackerman, J.T., and Eagles-Smith, C.A., 2009, Integrating toxicity risk in bird eggs and chicks-Using chick down feathers to estimate mercury concentrations in eggs: Environmental Science and Technology, v. 43, no. 2, p. 166-2,172.

Ackerman, J.T., Eagles-Smith, C.A., and Herzog, M.P., 2011, Bird mercury concentrations change rapidly as chicks age-Toxicological risk is highest at hatching and fledging: Environmental Science and Technology, v. 45, p. 5,418-5,425.

Ackerman, J.T., Eagles-Smith, C.A., Takekawa, J.Y., Bluso, J.D., and Adelsbach. T.L., 2008b, Mercury concentrations in blood and feathers of pre-breeding Forster's terns in relation to space use of San Francisco Bay habitats: Environmental Toxicology and Chemistry, v. 27, p. 897-908.

Ackerman, J.T., Eagles-Smith, C.A., Takekawa, J.Y., Demers, S.A., Adelsbach, T.L., Bluso, J.D., Miles, Warnock, N., Suchanek, T.H., and Schwarzbach, S.E., 2007a, Mercury concentrations and space use of pre-breeding American avocets and black-necked stilts in San Francisco Bay: Science of the Total Environment, v. 384, p. 452-466.

Ackerman, J T., Eagles-Smith, C.A., Takekawa, J.Y., and Iverson, S.A., 2008c: Survival of postfledging Forster's terns in relation to mercury exposure in San Francisco Bay: Ecotoxicology, v. 17, p. 789-801.

Ackerman, J.T., Herzog, M.P., and Schwarzbach, S.E., 2013b, Methylmercury is the predominant form of mercury in bird eggs-A synthesis: Environmental Science and Technology, v. 47, p. 2,052-2,060.

Ackerman, J.T., Overton, C.T., Casazza, M.L., Takekawa, J.Y., Eagles-Smith, R., C.A., Keister, A., and Herzog, M.P., 2012a, Does mercury contamination reduce body condition of endangered California clapper rails?: Environmental Pollution, v. 162, p. 439-448. 
Ackerman, J.T., Takekawa, J.Y., Eagles-Smith, C.A., and Iverson, S.A., 2008a, Mercury contamination and effects on survival of American avocet and black-necked stilt chicks in San Francisco Bay: Ecotoxicology, v. 17, p. 103-116.

Burnham, K.P., and Anderson, D.R., 2002, Model selection and multimodel inference-A practical information theoretic approach (2d ed.): New York, Springer-Verlag, 496 p.

Eagles-Smith, C.A., and Ackerman, J.T., 2009, Rapid changes in small fish mercury concentrations in estuarine wetlands-Implications for wildlife risk and monitoring programs, Environmental Science and Technology, v. 43, p. 8,658-8,664.

Eagles-Smith, C.A., Ackerman, J.T., De La Cruz, S.E.W., and Takekawa, J.Y., 2009a, Mercury bioaccumulation and risk to three waterbird foraging guilds is influenced by foraging ecology and breeding stage: Environmental Pollution, v. 157, p. 1,993-2,002.

Eagles-Smith, C.A., Ackerman, J.T., Yee, J., and Adelsbach, T.L., 2009b, Mercury demethylation in livers of four waterbird species - Evidence for dose-response thresholds with liver total mercury: Environmental Toxicology and Chemistry, v. 28, p. 568-577.

Goals Project, 1999, Baylands ecosystem habitat goals-A report of habitat recommendations: Prepared by the San Francisco Bay Area Wetlands Ecosystem Goals Project, U.S. Environmental Protection Agency, San Francisco, California; and San Francisco Bay Regional Water Quality Control Board, Oakland, California.

Herring, G., Ackerman, J.T., and Eagles-Smith, C.A., 2010, Embryo malposition as a potential mechanism for mercury-induced hatching failure in bird eggs: Environmental Toxicology and Chemistry, v. 29, p. 1,788-1,794.

Herring, G., Ackerman, J.T., and Herzog, M.P., 2012, Mercury exposure may suppress baseline corticosterone levels in juvenile birds: Environmental Science and Technology, v. 46, p. 6,339-6,346.

Hurley, J.P., Benoit, J.M., Babiarz, C.I., Shafer, M.M., Andren, A.W., Sullivan, J.R., Hammond, R., and Webb, D.A., 1995, Influences of watershed characteristics on mercury levels in Wisconsin rivers: Environmental Science and Technology, v. 29, p. 1,867-1,875.

Krabbenhoft, D.P., Wiener, J.G., Brumbaugh, W.G., Olson, M.L., DeWild, J.F., and Sabin, T.J., 1999, A national pilot study of mercury contamination of aquatic ecosystems along multiple gradients, in Morganwalp, D.W., and Buxton, H.T. eds., U.S. Geological Survey Toxic Substances Hydrology Program proceedings of technical meeting-Volume 2-Contamination of hydrologic systems and related ecosystems: U.S. Geological Survey Water Resource Investigations Report 99- 4018B, p. 147-160.

Marvin-DiPasquale, M., Agee, J., Bouse, R., and Jaffe, B., 2003, Microbial cycling of mercury in contaminated pelagic and wetland sediments of San Pablo Bay, California: Environmental Geology, v. 43, p. 260-267.

Marvin-DiPasquale, M., and Cox, M.H., 2007, Legacy mercury in Alviso Slough, South San Francisco Bay, California-Concentration, speciation and mobility: U.S. Geological Survey Open-File Report 2007-1240, p. 98, http://pubs.usgs.gov/of/2007/1240/.

Miles, A.K., and Ricca, M.A., 2010, Temporal and spatial distribution of sediment mercury at salt pond wetland restoration sites, San Francisco Bay, CA, USA: Science of the Total Environment, v. 408, p. 1,154-1,165. 
Pinheiro, J.C., and Bates, D.M., 2000, Mixed-effects models in S and S-PLUS: New York, Springer, $528 \mathrm{p}$.

U.S. Environmental Protection Agency, 2000, Test methods for evaluating solid waste, physical/chemical methods-Method 7473. SW 846, Update IVA: Springfield, Virginia, National Technical Information Service.

Waldron, M.C., Colman, J.A., and Breault, R.F., 2000, Distribution, hydrologic transport, and cycling of total mercury and methyl mercury in a contaminated river-reservoir-wetland system (Sudbury River, eastern Massachusetts): Canadian Journal of Fisheries and Aquatic Sciences, v. 57, p. 1,080-1,091. 
Publishing support provided by the U.S. Geological Survey

Science Publishing Network, Tacoma Publishing Service Center

For more information concerning the research in this report, contact the Director, Western Ecological Research Center

U.S. Geological Survey

3020 State University Drive East

Sacramento, California 95819

http://werc.usgs.gov/ 


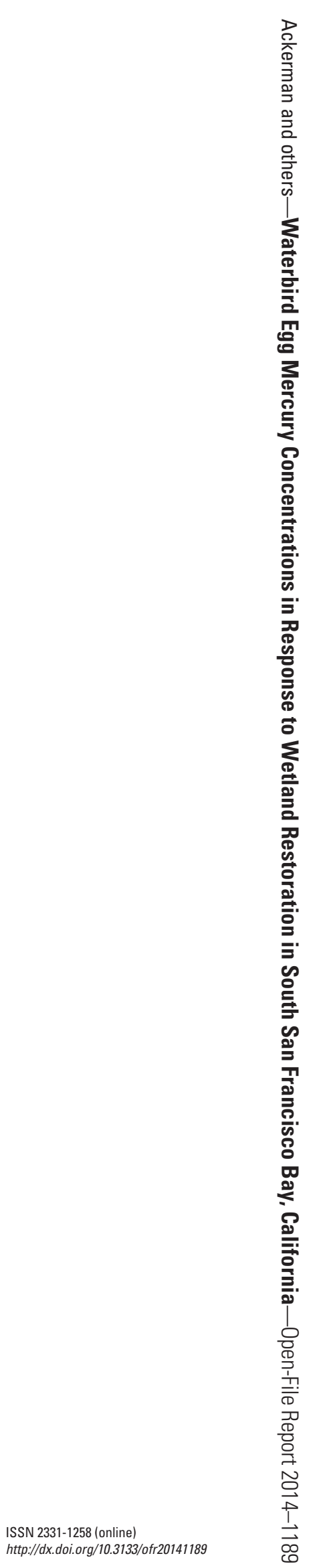

